NBER WORKING PAPER SERIES

\title{
DISSECTING THE EFFECT OF CREDIT SUPPLY ON TRADE: EVIDENCE FROM MATCHED CREDIT-EXPORT DATA
}

\author{
Daniel Paravisini \\ Veronica Rappoport \\ Philipp Schnabl \\ Daniel Wolfenzon \\ Working Paper 16975 \\ http://www.nber.org/papers/w16975 \\ NATIONAL BUREAU OF ECONOMIC RESEARCH \\ 1050 Massachusetts Avenue \\ Cambridge, MA 02138 \\ April 2011
}

We are grateful to Mitchell Canta, Paul Castillo, Roberto Chang, Raj Iyer, Sebnem Kalemni-Ozcan, Manuel Luy Molinie, Manju Puri, Marco Vega, and David Weinstein for helpful advice and discussions. We thank Diego Cisneros, Sergio Correia, Jorge Mogrovejo, Jorge Olcese, Javier Poggi, Adriana Valenzuela, and Lucciano Villacorta for outstanding help with the data. Juanita Gonzalez provided excellent research assistance. We thank participants at Arizona State University, CEMFI, Columbia University, Federal Reserve Bank of Peru, European Econometric Society, Federal Reserve Bank of Philadelphia, Fordham University, Harvard University, INSEAD, Instituto de Empresa, IPA Conference on Entrepreneurship and SME, LSE, MIT Sloan, NBER ITI, NBER IFM, NBER CF, Ohio State University, Rothschild Caesarea Center, Royal Economic Society, Royal Holloway University London, SED 2011, Stanford University, Tel Aviv University, Universidad Catolica de Chile, UC Davis, University of Michigan Ross School of Business, University of Minnesota Carlson School of Management, and World Bank seminars, workshops, and conferences for helpful comments. Paravisini, Rappoport, and Wolfenzon thank Jerome A. Chazen Institute of International Business for financial support. All errors are our own. The views expressed herein are those of the authors and do not necessarily reflect the views of the National Bureau of Economic Research.

NBER working papers are circulated for discussion and comment purposes. They have not been peerreviewed or been subject to the review by the NBER Board of Directors that accompanies official NBER publications.

(C) 2011 by Daniel Paravisini, Veronica Rappoport, Philipp Schnabl, and Daniel Wolfenzon. All rights reserved. Short sections of text, not to exceed two paragraphs, may be quoted without explicit permission provided that full credit, including (C) notice, is given to the source. 
Dissecting the Effect of Credit Supply on Trade: Evidence from Matched Credit-Export Data Daniel Paravisini, Veronica Rappoport, Philipp Schnabl, and Daniel Wolfenzon

NBER Working Paper No. 16975

April 2011, Revised August 2014

JEL No. F10,F30,F40,G15,G21,G32

\begin{abstract}
$\underline{\text { ABSTRACT }}$
We estimate the elasticity of exports to credit using matched customs and firm-level bank credit data from Peru. To account for non-credit determinants of exports, we compare changes in exports of the same product and to the same destination by firms borrowing from banks differentially affected by capital-flow reversals during the 2008 financial crisis. We find that credit shocks affect the intensive margin of exports, but have no significant impact on entry or exit of firms to new product and destination markets. Our results suggest that credit shortages reduce exports through raising the variable cost of production, rather than the cost of financing sunk entry investments.
\end{abstract}

Daniel Paravisini

Department of Finance

London School of Economics

Houghton Street

London WC2A 2AE

d.paravisini@1se.ac.uk

Veronica Rappoport

London School of Economics

v.e.rappoport@1se.ac.uk
Philipp Schnabl

Stern School of Business

New York University

44 West Fourth Street

New York, NY 10012

and NBER

schnabl@stern.nyu.edu

Daniel Wolfenzon

Graduate School of Business

Columbia University

Uris Hall, Room 808

3022 Broadway

New York, NY 10027

and NBER

dw2382@columbia.edu 


\section{Introduction}

The role of banks in the amplification of real economic fluctuations has been debated by policymakers and academics since the Great Depression (Friedman and Schwarz (1963), Bernanke (1983)). The basic premise is that funding shocks to banks during economic downturns increase the real cost of financial intermediation and reduce borrowers' access to credit and output. Through this channel, international commercial banks have been shown to represent an important source of contagion during periods of international capital reversals $1^{1}$ Although there is now a large body of evidence suggesting that negative bank credit shocks may affect economic activity, the magnitude of the sensitivity of output to bank funding shocks is unknown, and the underlying economic mechanisms behind this sensitivity are less understood $!^{2}$

In this paper, we study the effect of bank credit shocks on the export behavior of Peruvian firms during the 2008 financial crisis. The reversal of capital flows during the crisis negatively affected the foreign funding of banks operating in Peru. Using this funding shortage as a source of variation for credit supply, we document that banks that relied heavily on foreign funding before the financial crisis significantly reduced the supply of credit when capital flows reversed in 2008. Then, we exploit the disaggregated nature of the export data to compare the export growth of the same product and to the same destination across firms that borrowed from banks that were differentially affected by funding shocks. Comparing exports within narrowly defined markets is key to overcoming concerns that unobserved export demand and input market shocks might be correlated with the credit supply shock.

Our main result is that negative shocks to credit reduce the volume of exports for firms that continue exporting to a given product-destination market (i.e., the intensive margin) and has no impact on the probability that a firm exits or enters new product and destination markets. This result provides new insights into the relationship between exporters' production function and their use of credit. Consider, for example, the benchmark model of trade with sunk entry costs. ${ }^{3}$ In such a framework, a negative credit shock affects the entry margin, but once the initial investment is paid, credit fluctuations do not affect the intensive margin of exports. Yet, we find positive elasticities on the intensive margin, suggesting that credit shocks affect the variable cost of exporting. This would be the case, for example, if banks financed exporters' working capital, as in Feenstra et al. (2014) and Manova (2013). By increasing the unit cost of production, adverse credit conditions reduce the equilibrium size and profitability of exports.

The novelty of our empirical estimation relies on the uniqueness of the data. First,

\footnotetext{
${ }^{1}$ See Schnabl (2012), Cetorelli and Goldberg (2011), Puri et al. (2011), and IMF (2009).

${ }^{2}$ For early evidence see, for example, Bernanke and Blinder (1992), Kashyap et al. (1994), Kashyap and Stein (2000), and Peek and Rosengren (2000). And, more recently, Chodorow-Reich (2014), Iyer et al. (2014), and Jimenez et al. (2011).

${ }^{3}$ See, among others, Baldwin and Krugman (1989), Roberts and Tybout (1999), and Melitz (2003). Motivated by the important fixed costs involved in entering a new market-i.e. setting up distribution networks, marketing- Chaney (2005) develops a model where firms are liquidity constrained and must pay an export entry cost. Participation in the export market is, as a result, suboptimal.
} 
we observe outstanding credit for all Peruvian firms with each bank, as well as detailed banks' balance sheets. Then, rather than simply relying on the firm's outstanding credit level - which is an equilibrium outcome also determined by demand - we use a bank's dependence on foreign funding interacted with firms' debt composition across banks to construct an instrumental variable for firms' exposure to credit supply shocks. And, second, we use customs data, which include information on the identity of the exporting firm, product, destination, mode of transportation, volume, price, and date of each shipment. Using this information, we estimate regressions with a full set of product-destination-time dummies to control for non-credit shocks, such as time-varying export demand, changes in international prices, and input cost fluctuations. We find that both of these features of our estimation approach are crucial: a naive estimation, without instrumenting for credit supply and without accounting for non-credit shocks at the product-destination level, results in substantial estimation bias that may lead to erroneous conclusions, both qualitatively and quantitatively.

Our data and empirical approach allow us to obtain point-estimates of the elasticity of different dimensions of the export activity to credit. On the intensive margin, we find that a $10 \%$ reduction in the supply of credit reduces the volume of exports in the year after the shock by $1.95 \%$. We further show that firms adjust the intensive margin of exports in two ways - by changing the frequency of shipments of a given product to a given destination (with an elasticity of 0.10); and by adjusting the size of each shipment, with an elasticity of 0.9 and 0.11 when size is measured by volume and value, respectively. On the extensive margin, we find that credit shocks do not significantly affect the probability that a firm exits or enters a given export market. We also find that the credit arrangements between the exporter and the importer react to funding shocks to the exporting firm: after bank credit supply declines, exporting firms firms partially substitute towards trade credit with the importer. The magnitude of the effect is economically small: A 10\% reduction in bank lending triggers an increase of $0.2 \%$ in the fraction of the shipment paid in advanced by the importer.$^{4}$

This paper is related to a growing empirical literature that analyzes the role of credit in export activities. One strand of this literature focuses on the link between access to credit and the steady-state patterns of international trade and comparative advantages $5^{5}$ Our paper focuses not on the static patterns of exports, but on the effect of a credit shock on firms' export performance. Our results are more closely related to the work that analyzes the effects of credit disruptions on trade during the Great Trade Collapse of 2008 (see, for example, Bricongne et al. (2012), Bolton et al. (2011), Chor and Manova (2012), and Levchenko et al. (2010)). Most of the studies are based on the comparison of exports

\footnotetext{
${ }^{4}$ This is consistent with the findings of Antras and Foley (2014), who also document stickiness in the terms of the trade credit contracts between established trade partners during the 2008 financial crisis.

5 Beck (2002) and Manova (2013), for example, look at cross-country differences in financial conditions and the resulting patterns of exports across industries. And, related to static models of trade with heterogeneous firms and credit constraints, as in Chaney (2005), recent empirical literature has used cross-sectional firm-level data to analyze the effect of credit constraints on firms' participation in export markets. See, for example, Manova et al. (2014), Minetti and Zhu (2011), Muûls (2012) and Berman and Hericourt (2010).
} 
across industries presumed to differ in their sensitivity to credit. We can use our setting to test whether industry-level indicators, such as the Rajan and Zingales (1998) external dependence index, are correlated with the sensitivity of exports to credit shocks. We find no evidence in our setting to support the common assumption that sectors with high dependence on external finance have a higher export elasticity to credit supply shocks. Most likely, these measures capture exporters' long-term need for outside financing.

The paper is closely related to the recent literature on the real effects of the bank lending channel that uses firm-level instruments for credit shocks (see, for example, Amiti and Weinstein (2011), Carvalho et al. (2014), Chodorow-Reich (2014), Iyer et al. (2014), Jimenez et al. (2011), Kalemli-Ozcan et al. (2010), and Muûls (2012)). This literature compares firm-level outcomes - such as total sales, total exports, employment or investment - across firms affected differently by a credit shock. Comparing total exports across firms does not account for non-credit shocks to their different markets of operation, which, as we show in our setting, results in substantial estimation bias. For example, the point-estimate of the export elasticity to credit is biased downwards and not statistically different from zero when product-destination shocks are unaccounted for. Moreover, accounting for product-destination shocks crucially alters the cross-sectional correlation between the export sensitivity to credit and the variables typically used in the literature as a proxy for trade-specific financing demand (distance to destination, the mode of transportation (air vs. sea or ground), or whether the importer paid for exported goods in advance) ${ }^{6}$ In particular, the correlation between the export elasticity to credit and these proxies disappears when we control for product-destination shocks.

Our results highlight the importance of non-credit factors during the Great Trade Collapse 7 Indeed, in the case of Peru, our estimates suggest that while bank credit appears to have a first-order effect on exports, the bulk of the decline in exports is explained by the drop in international demand for Peruvian goods. Peruvian export volume growth was $-9.6 \%$ during the year following July 2008, almost 13 percentage points lower than in the previous year. Assuming that only banks with above-average foreign funding reduced their supply of credit, our estimates imply that the shock to bank funding accounts for only $8 \%$ of the missing volume of exports.

The rest of the paper proceeds as follows. Section 2 describes the economic environment and the data. Section 3 discusses the empirical strategy. Section 4 presents the results on the elasticity of exports to credit. Section 5 tests the validity of several key assumptions in existing empirical work aimed at measuring the effect of credit shocks on real economic activity. Section 6 concludes and performs a back of the envelope calculation of the contribution of finance to the overall export decline during the the 2008 crisis.

\footnotetext{
${ }^{6}$ The interaction of time-to-ship and credit frictions is emphasized in, among others, Amiti and Weinstein (2011), Leibovici and Waugh (2013), and Berman et al. (2012).

${ }^{\top}$ For evidence of non-financial determinants of the 2008 trade collapse, see Alessandria et al. (2010), Bems et al. (2010), Eaton et al. (2010), and Levchenko et al. (2010).
} 


\section{Background and Data Description}

This section describes the environment and the data. We first briefly describe the Peruvian economy - with an emphasis on the banking and export sectors - during the 2008 financial crisis. We then present the multiple data sets used in the empirical exercise.

\subsection{Background}

The 2008 financial crisis affected Peru through two main channels. The first was through the decline in the demand for Peruvian exports. Peruvian exports, which had been growing steadily over the decade prior to the 2008 financial crisis, suffered a sharp drop after 2008. Figure 2a shows the monthly (log) exports between 2007 and 2009. Peak to trough, monthly exports dropped by around $60 \%$ in value (40\% in volume) during the 2008 financial crisis ${ }^{8}$ The second channel was through the decline of portfolio capital inflows to Peru, which had been growing prior to the crisis. These flows stopped suddenly in mid 2008. As shown in Figure 2b, the decline in portfolio flows led to a dramatic decline in foreign funding to Peruvian banks.

Peru's GDP yearly growth declined from $11.7 \%$ in the second quarter of 2008 to $1.2 \%$ in the second quarter of 2009. Bank lending followed a similar trend: total bank loan growth dropped from 2.4\% between March and September 2008, to 1.6\% during the following six months $9^{9}$ This decline was concentrated in dollar-denominated loans, while lending in domestic currency (Soles) remained stable.

The drop in the volume of credit occurred concurrently with an increase in the cost of debt: the spread between dollar-denominated lending and deposit rates increased from $6.7 \%$ to $9.6 \%$ between March and December 2008; and the U.S. dollar appreciated more than $10 \%$ with respect to the domestic currency ${ }^{10}$ Although a decline in demand - due to the drop in export and import activities - may be partly to blame for the drop in credit, the rate increase highlights the importance of credit supply factors. Foreign funding to Peruvian banking sector decreased sharply. This, in turn, reduced the banking sector's loanable funds, especially for banks with a high share of foreign funding.

\subsection{Data Description}

We use three data sets: bank-level data on Peruvian banks; loan-level data on credit in the domestic banking sector; and customs data for Peruvian firms.

We collect the customs data from the website of the Peruvian tax agency (Superintendence of Tax Administration, or SUNAT). Collecting the export data involves using a

\footnotetext{
${ }^{8}$ The timing and magnitude of this decline aligns closely with the sharp collapse of world trade during the last quarter of 2008.

${ }^{9}$ The account of the 2008 financial crisis described in this subsection draws heavily on the "Report on Financial Stability," Banco Central de Reserva del Peru (2009).

${ }^{10}$ During the same period, due to active intervention by the Central Bank of Peru, the spread between active and passive Soles-denominated interest rates dropped from $21.7 \%$ to $17.2 \%$. These figures correspond to the average rates of commercial banks on lending and deposit (weighted).
} 
web crawler to download each individual export document. To validate the consistency of the data collection process, we compare the sum of the monthly total exports from our data, with the total monthly exports reported by the tax authority. On average, exports from the collected data add up to $99.98 \%$ of the exports reported by SUNAT.

The bank and loan data are from the Peruvian bank regulator, Superintendence of Banking, Insurance, and Pension Funds (SBS). The bank data consist of monthly financial statements for all of Peru's commercial banks from January 2007 to December 2009. Columns 1 to 3 in Table 1 provide descriptive statistics for the 41 financial institutions operating in Peru during this period. Most credit to exporting firms is concentrated among 13 commercial banks, described in columns 4 to 9, depending on their fraction of foreign funding relative to total assets. The remaining 28 banks are Savings and Loans (S\&L) institutions with limited exposure to foreign funding (columns 10 to 12). The loan data are a monthly panel of the outstanding debt of every firm with each bank operating in Peru. We match the loan data to export data using a unique firm identifier assigned by SUNAT for tax collection purposes.

Peruvian exports in 2009 totaled almost $\$ 27 \mathrm{bn}$, approximately $20 \%$ of Peru's GDP. North America and Asia are the main destinations of Peruvian exports; in particular, United States and China jointly account for approximately $30 \%$ of total exports. The main exports result from extractive activities: goods derived from gold and copper account for approximately $40 \%$ of Peruvian exports. Other important sectors are food products (coffee, asparagus, and fish) and textiles.

Panel 1 in Table 2 provides descriptive statistics of Peruvian exporters. Our data cover the universe of exporters - all firms with at least one export shipment between July 2007 and June 2009 (columns 1 and 2). The descriptive statistics correspond to the period July 2007-June 2008, prior to the capital flow reversal caused by the 2008 crisis. The average bank debt among the universe of exporters as of December 2007 is $\$ 1.01$ million, and the average level of exports is $\$ 3.3$ million FOB (Free On Board). The average firm exports to 2.7 destinations, out of a total of 198. The average firm exports 5.3 four-digit products (out of a total of 1,103 products with positive exports in the data). Our empirical analysis in Sections 4 and 5 is based on exporting firms with positive debt in the domestic banking sector, both, before and after the negative credit supply shock (columns 3 and 4). Firms in this subsample have larger debt, and their exports are more concentrated in a smaller number of products (Table 2, column 5). The empirical identification of the credit supply shock in Subsection 4.1 relies on the subsample of firms with two or more banking relationships (columns 7 and 8). These firms are even larger, in terms of both total exports and debt, than the baseline subsample in columns 3 and 4 .

The unit of observation in our baseline regressions is a firm-product-destination annual export flow. Panel 2 in Table 2 provides the descriptive statistics for the universe of 53,690 export flows (columns 1 and 2) and for the 47,810 observations that correspond to the subsample of exporters with positive bank debt (columns 3 and 4 ). The average annual export flow in our sample is US $\$ 184,800 \mathrm{FOB}(446,400 \mathrm{~kg})$, and is distributed into 2.17 shipments. Importers pay for more than $40 \%$ of these export flows in advance. About $40 \%$ are shipped by air, while the rest are transported by sea or ground. To estimate 
the effect of credit on the intensive margin of exports, the sample is restricted to around 16,500 firm-product-destination export flows that are positive (at least one shipment) both before and after the beginning of the capital flow reversal. The effect on the extensive margin is estimated using either the set of firm-product-destination export flows that a firm may enter after the capital flow reversal (entry margin) or those active before the capital flow reversal (exit margin).

\section{$3 \quad$ Empirical Strategy}

This section describes our approach to identifying the causal effect of credit supply on exports. Consider the following general characterization of the level of exports by firm $i$ of product $p$ to destination country $d$ at time $t, X_{i p d t}$ :

$$
X_{i p d t}=X_{i p d t}\left(H_{i p d t}, C_{i t}\right)
$$

The first argument, $H_{i p d t}$, represents determinants of exports other than credit supplyi.e., demand for product $p$ in country $d$; financial conditions in country $d$; the cost of inputs for producing product $p$; the productivity of firm $i$, etc. The second argument, $C_{i t}$, represents the amount of credit taken by the firm.

We are interested in estimating the elasticity of exports to credit: $\eta=\frac{\partial X_{i p d t}}{\partial C_{i t}} \frac{C_{i t}}{X_{i p d t}}$. The identification problem is that the amount of credit, $C_{i t}$, is an equilibrium outcome that depends on the supply of credit faced by the firm, $S_{i t}$, and the firm's demand for credit, which may be given by the same factors, $H_{i p d t}$, affecting the level of exports:

$$
C_{i t}=C_{i t}\left(H_{i p d t}, \ldots, S_{i t}\right)
$$

Our empirical strategy to address this problem is based on two pillars. First, we instrument for the supply of credit, using shocks to the balance sheet of the banks lending to firm $i$. This empirical approach obtains unbiased parameters if banks and firms are randomly matched. However, if banks specialize in firms' product or destination markets, the instrument may be correlated with factors that affect exports though channels other than the credit supply. For example, suppose that firms that export Men's Cotton Overcoats to the U.S. tend to borrow from banks that suffer a negative balance sheet shock during the crisis. If the demand for men's cotton overcoats in the U.S. drops disproportionately during the crisis, we would erroneously attribute this decline in exports to the credit supply shock.

To avoid potential bias due to non-random matching of firms and banks, a second pillar of our empirical strategy involves controlling for all unobserved heterogeneity in the crosssection with firm-product-destination fixed effects, and for shocks to the cost of inputs and demand of exports with product-country-time dummies.11 As a result, our estimation compares variation in exports within product-destinations instead of comparing variation

\footnotetext{
${ }^{11}$ Subsection 5.1 shows that the impact of the credit shock on export is severely misestimated if the model does not control for heterogeneity of non-credit factors across product and destinations.
} 
in total exports across firms. In the example above, our estimation procedure compares the change in men's cotton overcoat exports to the U.S. by a firm that is linked to a negatively affected bank with the corresponding change in a firm whose lender is not affected.

The identification assumption is that factors other than bank credit that may affect the exports of men's cotton overcoats to the U.S. differently across these two firms are not related to the debt composition of banks from which the two firms borrow. Note that this assumption is much weaker than the one required for estimation using total exports at the firm level, which does not control for shocks in firms' export or input markets. The identification assumption is violated if a firm's bank affiliation is correlated with: 1) demand heterogeneity within a product-destination (e.g., product quality), or 2) other non-credit firm-level shocks (e.g., firm's direct dependence on foreign funding, not mediated by banks). We discuss and test the validity of these assumptions in Subsection 4.6. where we show that the elasticity point estimates are unchanged when we allow the effect of credit to exports to vary across firms that export products of different quality; firms that have different currency composition of their funding; single- and multi-product firms; and small and large firms measured both by volume of exports and by number of destinations. This robustness provides strong support for our identification assumption.

Formally, we estimate $\eta^{I}$, the elasticity of the intensive margin of exports to credit, using the following empirical model:

$$
\ln \left(X_{i p d t}\right)=\eta^{I} \cdot \ln \left(C_{i t}\right)+\delta_{i p d}+\alpha_{p d t}+\varepsilon_{i p d t},
$$

where, as in equation (1) above, $X_{i p d t}$ represents the exports by firm $i$ of product $p$ to destination country $d$ at time $t$, and $C_{i t}$ is the the sum of all outstanding credit from the banking sector to firm $i$ at time $t$. The right-hand side includes two sets of dummy variables: $\delta_{i p d}$ accounts for the unobserved heterogeneity of product $p$ exported to destination $d$ by firm $i$, and $\alpha_{p d t}$ accounts for product-destination-time shocks. The first component captures, for example, the managerial ability in firm $i$, or the firm's knowledge of the market for product $p$ in destination $d$. The second component captures changes in the cost of production of good $p$, variations in the transport cost for product $p$ to destination $d$, or any fluctuation in the demand for product $p$ at destination $d$.

To measure the extensive margin elasticity - the change in the probability that firm $i$ starts/stops exporting product $p$ to destination $d$ - we use the following linear probability model:

$$
E_{i p d t}=\eta^{E} \cdot \ln \left(C_{i t}\right)+\delta_{i}+\alpha_{p d t}+\varepsilon_{\cdot i p d t},
$$

We are interested in measuring separately the elasticity of entry and exit to a credit shock, so we estimate two specifications: in the entry specification, $E_{i p d t}$ is an indicator variable for whether exports by firm $i$ of product $p$ to destination $d$ is positive at time $t$, conditioning on exports being zero in the previous period. In the exit specification, $E_{i p d t}$ is equal to one if firm $i$ does not export product $p$ to destination $d$ at time $t$, conditioning on exports being positive in the previous period.

Note a key difference between the extensive margin specification (4) and the intensive margin specification (3): the extensive margin contains only firm fixed-effects, instead of 
firm-product-destination fixed-effects. This is by construction, since a firm that enters (exits) a product-destination market cannot enter (exit) in the same product-destination market the following period. Thus, $\eta^{E}$ can be interpreted as a firm-level semi-elasticity: it measures the change in the probability that a firm enters/exits a new product-destination market that is induced by a one-percentage-point change in credit supply.

We estimate equations 3 and 4 using shocks to the financial conditions of the banks lending to firm $i$ as an instrument for the amount of credit received by firm $i$ at time $t$, $C_{i t}$. We next explain the economic rationale behind the instrument and further discuss the identification hypothesis behind the instrumental variable (IV) estimation.

\subsection{Capital Flow Reversals, Bank Foreign Funding and Credit Supply}

The hypothesis behind the instrumental variable approach is that the contraction in credit supply after the capital flow reversal was larger for banks that relied more on foreign funding before the crisis. In this subsection, we present the within-firm estimation strategy to disentangle credit supply from changes in the demand for credit, and we then test our assumption. 12

We first document that the share of foreign funding was heterogeneous across banks before the crisis. Table 1 shows descriptive statistics for the 41 banks in our sample, 13 commercial banks and 28 S\&Ls at year-end 2006. The average foreign funding as a fraction of assets is $5.5 \%$, and the median is $0.2 \%$. The skewness in the cross-sectional distribution of foreign funding is due mainly to the large number of small S\&Ls that use low amounts of foreign funding. Excluding S\&Ls, the average foreign funding for Commercial Banks is about $10 \%$ and also exhibits substantial heterogeneity. Foreign funding represents close to $20 \%$ of the assets of the four commercial banks with above-average foreign exposure, but only $5 \%$ of the assets of banks with below-average exposure (Table 1 , columns 4 and 7) 13

The within-firm estimator compares the change in the amount of lending by banks with different dependence on foreign funding to the same firm, before and after the capital flow reversal. Based on the evolution of total foreign lending to Peruvian banks in Figure 2b, we set July 2008 as the starting date for the capital reversals. This leads to the following empirical model:

$$
\ln \left(C_{i b t}\right)=\theta_{i b}+\mu_{i t}+\beta \cdot f\left(F D_{b}\right) \times \text { Post }_{t}+\nu_{i b t} .
$$

$C_{i b t}$ is the average outstanding debt of firm $i$ with bank $b$ during the intervals $t=$ $\{$ Pre, Post $\}$, where the Pre and Post periods correspond to the 12 months before and after July 2008. $f\left(F D_{b}\right)$ is an increasing function of the share of foreign funding of bank

\footnotetext{
${ }^{12}$ This procedure has been used in Gan (2007), Khwaja and Mian (2008), Paravisini (2008), Iyer et al. (2014), Iyer and Peydro (2011), Schnabl (2012), Jimenez et al. (2011) and Jimenez et al. (2012).

${ }^{13}$ For example, the foreign funding of HSBC and Banco Santander, two foreign-owned banks operating in Peru, were $17.7 \%$ and $2.2 \%$ of assets, respectively, in 2006.
} 
$b$ before the capital flow reversal, which may be non-linear, and Post $t$ is a dummy equal to one when $t=$ Post.

The regression includes firm-bank fixed-effects, $\theta_{i b}$, which control for all (time-invariant) unobserved heterogeneity in the demand and supply of credit. It also includes a full set of firm-time dummies, $\mu_{i t}$, that control for the firm-specific evolution in overall credit demand during the period under analysis. As long as changes in a firm's demand for credit are equally spread across different lenders in expectation, the coefficient $\beta$ measures how credit supply by commercial banks changes with foreign funding.

\subsection{Instrument}

We construct the firm-level instrument for estimating specifications (3) and (4) in two steps. First, we calculate each firm's exposure to the credit supply shock. We assume (and later test) whether firms that were more exposed to banks with high foreign funding experienced a larger decline in credit supply after the capital flow reversals. We use the average foreign dependence of the firm's bank, weighted by the fraction of credit from each bank, as an instrument for the firm's exposure to the credit supply shock:

$$
F_{i}=\sum_{b} \omega_{i b} f\left(F D_{b}\right)
$$

where $\omega_{i b}$ is the share of bank $b$ in total credit of firm $i$, and $f\left(F D_{b}\right)$ is the dependence on foreign funding from specification (5), which is a function of the bank's share of foreign funding, $F D_{b}$. Both $\omega_{i b}$ and $F D_{b}$ are measured at year-end 2006.

The second step is interacting the measure of firms' exposure with a time indicator of the capital flow reversal:

$$
F_{i t}=F_{i} \cdot \text { Post }_{t},
$$

where Post $_{t}$ is an indicator variable that turns to one after July 2008, when the decline in foreign funding started.

The cross-sectional variation in $F_{i}$ comes from two sources: the firm-specific amount of credit that it receives from each bank in 2006; and the heterogeneous dependence on foreign capital across banks. The classification of banks and firms in 2006 reduces the likelihood that bank foreign dependence and firm-bank matching were endogenously chosen in anticipation of the crisis. The time series variation in $F_{i t}$ is given by the aggregate decline of foreign bank funding in the Peruvian economy.

We consider different parametrizations of the functional form $f($.$) . In Subsection$ 4.1. we analyze non-parametrically the relationship between bank foreign funding and credit supply. And, in Subsection 4.2, we use the Least Absolute Shrinkage and Selection Operator (LASSO) method in Belloni et al. (2012) to select the optimal parametrization of the instrument and to avoid choosing the functional form of the instrument in an ad hoc manner 14 We test the robustness of the results to alternative definitions of the instrument

\footnotetext{
${ }^{14}$ The LASSO estimator augments the error minimization problem of the first-stage regression with a kinked penalty function on each non-zero parameter of $f($.$) that induces the solution to the first-stage to$ have many zeroes.
} 
in Subsection 4.6.

\section{Effect of Credit Supply Shock on Exports}

In this section, we use the methodology described above to, first, corroborate that the bank's share of capital funded with foreign capital predicts a negative credit supply shock to its borrowers during the Post period; and, second, to estimate the elasticity of exports to credit on the intensive and extensive margins.

Since our empirical strategy relies crucially on accounting for shocks to export demand and input cost, we define the margin of exports at the product-destination level. The intensive margin corresponds to firm exports of a given product to a given destination that are positive in both the Pre and Post periods. The extensive margin corresponds to the probability that an exporting firm enters or exits a product-destination market. In the baseline specifications, we define products at the 4-digit level according to the Harmonized System (HS). As a result, our estimations are obtained from exports variation within about 6,000 product-destinations.

\subsection{Identification of the Credit Supply Shock}

This subsection formally tests the identification assumption. We estimate specification (5) after first differencing to eliminate the firm-bank time-invariant fixed-effects, $\theta_{i b}$. The resulting estimation equation is:

$$
\ln \left(C_{i b P o s t}\right)-\ln \left(C_{i b P r e}\right)=\mu_{i}^{\prime}+\beta \cdot f\left(F D_{b}\right)+\nu_{i b}
$$

The firm dummies $\mu_{i}^{\prime}$ absorb all changes in credit demand by the firm, $\mu_{i}^{\prime}=\mu_{i \text { Post }}-\mu_{i \text { Pre }}$ in equation (5).

We inspect non-parametrically the relationship between a bank's share of foreign funding and the change in credit to exporting firms during the crisis (left-hand side of equation (8)). Figure 3a plots smoothed local polynomial regressions of the change in (log) credit by bank $b$ to firm $i$ between the Pre and Post periods, $\ln \left(C_{i b \text { Post }}\right)-\ln \left(C_{i b \text { Pre }}\right)$, on the fraction of assets funded with foreign debt, $F D_{b}$. The plot indicates that banks with a low exposure to foreign funding expanded total lending after the crisis, while banks with high exposure reduced total lending. To explore the relationship between banks' credit supply and foreign funding we replicate Figure $3 \mathrm{a}$ plotting in the vertical axis the residuals of a regression of changes in (log) credit by bank $b$ to firm $i$ on a full set of firm fixed-effects, which account for changes in demand of credit by the firms. A similar pattern appears: banks with high levels of foreign funding reduce supply of credit relative to banks with low levels of exposure. Credit supply does not change with foreign funding at relatively low exposures (below 7\% foreign funding) and declines sharply at higher exposure levels (between $7 \%$ and 10\%). To account for the potential non-linearities observed in the plot we present estimates of equation (5) using two alternative assumptions for the functional form of exposure: (i) a linear function of the bank's share of foreign debt, $f\left(F D_{b}\right)=F D_{b}$, 
and (ii) an indicator function equal to one if the bank's share of foreign funding is above $10 \%$, the mean amongst commercial banks, $f\left(F D_{b}\right)=D\left(F B_{b}>\overline{F B}\right)$.

Table 3 shows the estimates of $\beta$ from equation (8), with standard errors clustered at the bank level. We find that, indeed, banks with a higher fraction of foreign funding reduced credit supply more after the capital flow reversal. The point estimate on the linear functional form for bank exposure $\left(f\left(F D_{b}\right)=F D_{b}\right)$ is -1.88 (column 1 ), which implies that a one-percentage-point increase in the fraction of foreign funding before the crisis predicts a 1.88-percentage-point additional decline in credit supply. The point estimate on the indicator of exposure if bank- $b$ 's share of foreign funding was higher than $10 \%$ in December $2006\left(f\left(F D_{b}\right)=D\left(F D_{b}>\overline{F D}\right)\right)$ is -0.168 , which implies that banks with an above-average share of foreign funding reduced the credit supply by $17 \%$ relative to banks with a below-average share of foreign funding. The t-statistic on the binary definition of exposure (3.65) is substantially larger than that on the linear definition (1.86). This suggests that a simple binary classification of banks in two categories, exposed and notexposed to a foreign funding shock, provides an accurate characterization of how the change in credit supply varied across banks during the crisis.

\subsection{First Stage and Instrumental Variable Choice}

The results in Table 3 demonstrate that a bank's foreign funding was negatively correlated with its change in supply of credit during the crisis. This does not necessarily imply that firms that borrowed from these banks experienced a shortage of credit because firms may have been able to offset a credit supply shock to one of their lenders by borrowing from another lender. Hence, we need to test whether the bank credit supply shock affected the total credit obtained by firms. This corresponds to the first-stage regression of the Two-Stage-Least-Squares estimator of (3). The first stage tests whether the instrument is correlated with the total amount of credit received by the borrowers of exposed banks. Taking first-differences to eliminate the firm-bank fixed-effects, the first stage is:

$$
\ln \left(C_{i \text { Post }}\right)-\ln \left(C_{i \text { Pre }}\right)=\gamma_{p d}^{\prime}+\alpha F_{i}+\epsilon_{i}
$$

where the dummy $\gamma_{p d}^{\prime}=\gamma_{p d P o s t}-\gamma_{p d P r e}$ controls for factors affecting the product-destination supplied by the firm. The firm-level instrument $F_{i}$ is defined in equation (7).

Table 4 presents the results of first-stage specifications for different functional forms of the instrument. In column 1 the firm-level instrument is defined based on the binary measure of bank foreign dependence: the share of credit received from banks with an above-average share of foreign funding, $F_{i}=\sum_{b} \omega_{i b} D\left(F D_{b}>\overline{F D}\right)$. In column 2 , the instrumental variable is defined based on a linear measure of bank exposure: the average of the foreign funding of the lenders to a firm, weighted by the fraction of credit from each lender, $F_{i}=\sum_{b} \omega_{i b} F D_{b}$. The coefficient on the instrument is negative and statistically significant at the $1 \%$ level in both specifications, indicating that firms that borrowed from exposed banks did experience a decline in total credit during the crisis. Both definitions of the instrument imply a strong first stage with F-statistics of 155.5 (binary) and 20.5 (linear). 
To select the functional form of the instrumental variable, we perform the LASSO estimation of the first stage including as instruments: (1) a binary measure of banks' foreign dependence, $f\left(F D_{b}\right)=D\left(F D_{b}>\overline{F D}\right)$; and (2) an eighth-degree polynomial of banks' foreign funding, $f\left(F D_{b}\right)=a_{1} F D_{b}+a_{2} F D_{b}^{2}+\ldots+a_{8} F D_{b}^{8}$. LASSO selects the binary measure of banks' foreign dependence as the optimal instrument ${ }^{15}$ Therefore, for the baseline estimation, we use the following functional form of the instrumental variable defined in (7):

$$
F_{i}=\sum_{b} \omega_{i b} D\left(F D_{b}>10 \%\right) .
$$

To test the robustness of the results to alternative functional forms of the instrument, we perform LASSO on the first stage excluding the binary instrument. In this case, LASSO selects the instruments based on a third-degree polynomial of the lenders' shares of foreign funding. We show the first-stage estimates using the third-degree polynomial instrument in Table (4), column 3, and we use this third-degree polynomial as an instrument to perform robustness tests of the instrumental variable results in subsection 4.6 .

\subsection{Intensive Margin of Exports}

This subsection analyzes the effect of a credit supply shock on the intensive margin of exports. A key advantage of our estimation approach that compares exports within product-destination markets is that one can measure real exports in volume, rather than by value. By construction, this eliminates from the estimation any potential confounding effect of changes in international prices during the crisis. Thus, our baseline specifications are all estimated using exports measured in volume, and we show in subsection 4.6 that the results are robust to the alternative measure.

Export data are highly seasonal, so we collapse the panel into one-year periods before and after the capital flow reversal to avoid estimation bias due to serial correlation and seasonality. The Pre and Post periods correspond to the 12 months before and after July 2008. Thus, exports, $X_{i p d t}$, corresponds to the sum of the volume of exports (in kilograms) of product $p$ to destination $d$ by firm $i$ in the period $t$ for those firm-productdestination export flows that are active in the two periods, $t=\{$ Pre, Post $\}$. And credit, $C_{i t}$, corresponds to the average outstanding credit balance (in local currency) of firm $i$ in period $t$.

We estimate equation (3) by first-differencing to eliminate the firm-product-destination time-invariant fixed-effects, $\delta_{i p d}$. The resulting estimation equation is:

$$
\ln \left(X_{\text {ipdPost }}\right)-\ln \left(X_{i p d P r e}\right)=\alpha_{p d}^{\prime}+\eta^{I} \cdot\left[\ln \left(C_{i \text { Post }}\right)-\ln \left(C_{i P r e}\right)\right]+\varepsilon_{i p d}^{\prime} .
$$

The product-destination dummies, $\alpha_{p d}^{\prime}=\alpha_{p d P o s t}-\alpha_{p d P r e}$ in equation (3), absorb all

\footnotetext{
${ }^{15}$ We use the LASSO and Post-LASSO shooting code provided on Christian Hansen's University of Chicago web page: http://faculty.chicagobooth.edu/christian.hansen/research/. The LASSO point estimate of the coefficient on the selected instrument is -.752 , close to the first-stage estimate of -0.991 in Table 4 - the Post-LASSO estimate.
} 
demand fluctuations of product $p$ in destination $d$. The supply of credit to firm $i$ is instrumented with $F_{i}$, defined in 10 .

The results of the Ordinary Least Square (OLS) and the Instrumental Variable (IV) estimations of the export elasticity to credit supply in specification (11) are presented in presented in Table 5, columns 1 and 2. When the credit shock to the firm is not instrumented, the OLS estimate of the elasticity is 0.025 (column 1). When the credit supply shock to the firm is instrumented using the funding shock to the lending bank, the IV estimate of the elasticity is 0.195 (column 2). The point estimate implies that a $10 \%$ reduction in the stock of credit results in a decline of $1.95 \%$ in the volume of yearly export flows.

\subsubsection{OLS Bias: Credit Demand and Supply}

The IV estimate of the export elasticity to finance is 7.8 times larger than the OLS estimate. The IV estimate corresponds to the change in exports due to changes in the credit supply - demand variation is absorbed by the product-destination dummies, $\alpha_{p d}$. The OLS estimate, however, corresponds to a regression of changes in exports on total credit variation, induced by credit demand and supply factors. In the simplest scenario, where credit demand and supply shocks are uncorrelated, credit demand variation is equivalent to measurement error, and the OLS estimate is biased towards zero due to classical attenuation bias.

We can use the magnitude of the OLS bias to back out the relative importance of demand and supply determinants of credit. In our setting, the magnitude of the attenuation bias increases with the fraction of the total credit variation that is explained by credit demand factors. First-differencing further increases the magnitude of the attenuation bias when the independent variable (i.e., the supply of credit) exhibits serial correlation (see Arellano (2003)).

With no serial correlation in credit supply, demand variation must explain around $87 \%$ of the total variation in credit to obtain a bias of $\frac{\beta}{\beta_{O L S}}$ above $7 .{ }^{16}$ In Monte-Carlo simulations - shown in the Internet Appendix - where we add serial correlation in credit supply through unobserved firm heterogeneity, we find that the OLS bias can be seven to ten times the IV estimate when demand explains $60 \%$ of the variation in total credit 17 Thus, the magnitude of the OLS bias indicates that supply-side factors explain less than half of the variation in total credit during the crisis.

\subsubsection{Heterogeneity across Export Flows}

The intensive margin elasticity is estimated for firm-product-destination flows active in the Pre and Post periods. Thus, our intensive margin estimate is a Local Average Treatment Effect (LATE) for export flows that continue to be active during the crisis.

\footnotetext{
${ }^{16}$ Using the classic measurement error bias formula, $\frac{\beta}{\beta_{O L S}}=1+\frac{\sigma_{\text {demand }}^{2}}{\sigma_{\text {supply }}^{2}}=1+\frac{.87}{.13}=7.69$.

${ }^{17}$ The $R^{2}$ of the within-firm specification (8) including only the product-destination dummies is $62 \%$. This is our best approximation of the minimum amount of variation in total credit that can be explained by demand factors.
} 
In this subsection, we address the question of whether the estimated intensive margin elasticity is representative of export flows that were discontinued during the crisis. In other words, we assess whether the LATE estimate is an upper or a lower bound for the Average Treatment Effect for the population.

We follow the approach in Mulligan and Rubinstein (2008) and document the heterogeneity of the intensive margin elasticity for export flows with different probabilities of continuation. We first estimate the probability that a firm-product-destination export flow that is active in the Pre period continues to be active in the Post period $\left(\widehat{P}\left(X_{\text {ipdPost }}>0 \mid X_{\text {ipdPre }}>0\right)\right)$. For this estimate, we use a Probit model with the following explanatory variables: the size of the export flow in the Pre period $\left(\ln X_{i p d}\right)$; the size of the firm's total exports $\left(\ln X_{i}\right)$; the overall stock on credit $\left(\ln C_{i}\right)$; and the measure of exposure, $F_{i}$, defined in equation (10). The parameters of the Probit regression reported in column 1 of Table 5 indicate that larger export flows, as well as flows by larger firms with more credit, are more likely to continue during the crisis. Once firm credit is included in the regression, the instrument for credit supply shock $\left(F_{i}\right)$ does not significantly affect the probability that an existing export flow remains active. This is consistent with the exclusion restriction of the instrumental variable estimation of the extensive margin of exports (next subsection), as it indicates that the instrument affects the exit margin only through credit.

Based on the probit estimates of the probability of continuation for each flow, we estimate the intensive margin elasticity on subsamples that include only the export flows above the 20th, 40th, 60th and 80th percentiles of the continuation probability distri-

bution. That is, subsamples defined by: $\left\{i p d \mid \widehat{P}\left(X_{\text {ipdPost }}>0 \mid X_{\text {ipdPre }}>0\right) \geq \alpha\right\}$ for $\alpha=0.42,0.56,0.68,0.79$.

The results are reported in columns 3 to 6 of Table 5 and are shown graphically in Figure 3. For comparison, the table also includes the sample defined by $\alpha=0$, which corresponds to the full sample used in column 2. The point estimates of the intensive margin elasticity to credit are similar across export flows with different probability of continuation. As is clear from Figure 3, the standard errors increase as we restrict the data to a higher cutoff for the continuation probability, which is likely caused by the smaller sample size. Most importantly, we cannot reject the hypothesis that the estimates are similar across the different samples, which indicates that our LATE estimate of the intensive margin elasticity is representative of the entire population.

\subsection{Extensive Margin of Exports}

We analyze the effect of a credit supply shock on the probability that an exporting firm abandons or enters a product-destination export market using estimating equation (4) 18 As in the previous subsection, we collapse the time series into two periods, Pre and Post, which correspond to the 12 months before and after July 2008. The sample contains a large number of intermittent export flows; thus, we consider a firm-product-destination

\footnotetext{
${ }^{18}$ In an earlier version of this paper, we computed the effect of the credit shock on the number of firms entering and exiting product-destination markets. The results were qualitatively similar.
} 
flow to be active at time $t$ if it registered positive exports at any time during those 12 months.

The definition of the sample of export flows at risk of exit is straightforward: it includes all firm-product-destination flows active in the Pre period. The definition of the potential entrants is less straightforward because, in principle, any firm operating in Peru that is currently not exporting is a potential entrant to any of the product-destinations in the unrestricted universe of potential markets. Computational limitations do not permit us to consider any firm as a potential entrant to any market because the number of observations in the data set would be measured in hundreds of millions. We adopt a narrower definition of potential entrants and entry markets by imposing the following restrictions: 1) we consider only firms that are already exporting to any product-destination in the Pre period, which implies that the probability of entry is measured as the probability that an exporter enters a new product-destination market; and 2) we restrict the universe of potential new products to those 4-digit HS categories within the set of 2-digit HS industries exported to by the firm in the Pre period. ${ }^{19}$ The resulting number of potential new firm-product-destinations is 4,161,451. Despite the restrictions, this number is large relative to the actual new entries: in the Pre period, the probability of entering a new market is $0.5 \%$ (i.e., the fraction of potential new firm-product-destinations in the year before the Pre period in which an entry occurs).

Since entry and exit represent changes in the exporting status at the firm-productdestination level, we cannot first-difference equation (4) to eliminate the firm fixed-effect, $\delta_{i}$. Therefore, we estimate the equation in levels, including the firm dummies that control for any time-invariant characteristic of the firm and product-destination-time dummies, $\alpha_{p d t}$, that control for changes in demand, international prices, etc. Credit supply to firm $i$ is instrumented with $F_{i} \times$ Post $_{t}$, defined in equation (10).

The results are presented in Table 6. Changes in credit supply do not significantly affect the extensive margin. This finding holds for both exit and entry and for both IV and OLS estimation.

\subsection{Effect on Freight Characteristics and Trade Credit}

Firms may adjust other dimensions of their export activity when subject to a negative credit shock. In this subsection, we explore the effect of a decline in credit supply on freight policies and the trade credit conditions with the importer. We estimate specifications based on (11), using the following left-hand-side variables: (i) change in frequency of shipments for a firm-product-destination export flow, $\Delta \ln \left(\right.$ ShipFreq $\left._{i p d}\right)$; (ii) change in the average size of shipments (in volume) for a given export flow, $\Delta \ln \left(S h i p V o l_{i p d}\right.$ ); (iii) change in the average shipment value $(\$ F O B)$ for a given flow $\Delta \ln \left(\right.$ ShipVal $\left.l_{i p d}\right)$; (iv) change in the fraction of the annual flow (value FOB) transported by air, as opposed to sea and ground, $\Delta \ln \left(\right.$ FracAir $\left._{i p d}\right)$; and (v) change in the fraction of the annual flow (value FOB) paid in advance by the importer $\Delta \ln \left(\right.$ FracCash $\left._{i p d}\right)$.

\footnotetext{
${ }^{19}$ The universe of products and destinations considered here corresponds to any 4-digit HS category or country ever exported to by a Peruvian firm during our sample period.
} 
Table 7 shows the results. A negative shock to credit supply is found to reduce the frequency of shipments, with elasticity 0.11 , significant at the $1 \%$ level (column 1). Firms also react by reducing the size of the shipment, both in value and in volume, with elasticity 0.085 and 0.106 , respectively (columns 2 and 3 ).

Holding the product and the destination constant, firms do not increase the share of exports shipped by air (as opposed to sea or ground) after a negative credit supply shock (column 4). Finally, the fraction of the transaction value paid in advance by the importer is sensitive to the decline in credit supply (column 5). However, the magnitude of the effect is economically small: A $10 \%$ reduction in bank lending triggers an increase of $0.24 \%$ in the fraction of the shipment paid in advanced by the importer. This result is consistent with the findings in Antras and Foley (2014), who document stickiness in the terms of the trade credit contracts between established trade partners during the 2008 financial crisis.

\subsection{Identification and Robustness Tests}

As mentioned in Section 3, the elasticity estimates are biased if firms associated with banks with high foreign funding experience a disproportionate negative shock to exports, relative to other firms exporting to the same product-destination for reasons other than bank credit. This could occur, for example, if firms that borrow from exposed banks export products of a higher quality (within the same 4-digit HS code), and the demand for higher-quality products dropped more during the crisis. It could also occur if firms with high foreign-currency-denominated funding borrow from banks with high foreign funding, and the capital flow reversals affect the balance sheet of firms directly and not through bank lending. In this section, we perform identification tests to account for potential shocks correlated with bank affiliation.

In the first identification test, we estimate the elasticity of the intensive margin, measuring exports in dollar FOB values. If the identification assumption is violated because there are demand or input price changes within product-destination markets that are correlated with bank affiliation, these changes should be reflected in prices, and, as a result, the elasticities measured in export volumes should be different than the elasticities measured in values. On the contrary, if firms exporting to the same market face price changes that are orthogonal to their bank affiliation, then the product-destination dummies should absorb these effects, resulting in the same estimates of export elasticities whether measured in volume or value. The result in Panel 1 of Table 8 confirms that the volume and value elasticities are of the same order of magnitude and statistically indistinguishable.

Next, we test whether narrowing the definition of an export market or whether considering only homogeneous goods changes our elasticity estimates. Panel 2 shows the export elasticity to credit when products are aggregated at the HS 6-digit level. This specification controls for shocks in 8,568 distinct product-destination markets, reducing the scope of quality difference within each market. We find that our estimates are effectively unchanged. 
In Panel 3, we restrict the sample to export flows of homogeneous goods only, according to the product classification in Rauch (1999). These goods are considered to be less differentiated in terms of quality and other potential unobservable characteristics. We find that the elasticities of the intensive and extensive margins are statistically identical to those in the baseline regression.

An alternative way to test for unaccounted shocks correlated with bank affiliation is to explicitly control for them. In the fourth identification test, we augment equations (11) and (4) using a set of observable firm and export flow characteristics in the Pre period as control variables: average unit price of exports at the firm-product-destination level; average fraction of debt denominated in foreign currency; total exports; number of products; and number of destinations at the firm level. Including these pre-determined variables in the first differenced specification (11) is equivalent to including them interacted with time dummies in the panel specification in levels. Thus, this augmented specification controls for heterogeneity in the evolution of exports after the crisis along the dimensions of product quality (high unit price within a 4-digit HS classification), firm external exposure, and firm size. The elasticity of the intensive margin and of the extensive margin are statistically indistinguishable from the baseline regressions. (Panel 4, Table 8).

In Panel 5, we expand the Post-period to include 24 months after the capital flow reversal in July 2008. The result on the intensive margin is not significantly different from the baseline regression. The probability of entering a new product-destination market, on the other hand, is significantly affected by the credit shock when the period of analysis is extended to two years after the shock. Evaluated at the average probability of entry in the Pre period, $0.5 \%$, a $10 \%$ drop in credit supply reduces the probability of entry by only 0.01 percentage points, to $0.49 \%$.

In Panels 6 and 7, we test the robustness of the results to the definition of the instrument. We verify that the results are not sensitive to the date at which we measure the share of foreign funding of the banks or the firm composition of credit across banks. In our baseline regressions, we define this measure according to figures from December 2006, prior to the reversal of capital flows. In Panel 6, the instrument is defined according to bank and firm figures from December 2007, at the peak of the foreign capital inflows. In Panel 7, we alter the functional form of the instrumental variable. Credit is instrumented with a 3-degree polynomial on the average foreign funding of the firm's lenders, weighted by the firm's outstanding debt: $F_{i}=\sum_{b} \omega_{i b} F D_{b}$ (the first stage is shown in Table 4, column 3). In all cases, the elasticities are statistically undistinguishable from the baseline results in Tables 5 and 6. In Panel 7, the elasticity of the exit margin is different from zero at the $10 \%$ level.

Finally, we explore the possibility that firms associated with exposed banks were simply on a different export and borrowing growth path before the crisis. If this was, in fact, the case, our estimates could be capturing such pre-existing differences across the two groups of firms and not the effect of the credit shock. We perform the following placebo test: we estimate equations (11) and (4) lagging the debt and export measures one year, as if the capital flow reversals had occurred in 2007 instead of 2008. That is, for $t=\{$ Pre -1, Pre $\}$, where Pre is, as above, the period July 2007-July 2008, and 
Pre -1 corresponds to the previous 12 months. The elasticities of both the intensive and extensive margins of exports, reported in Panel 8 of Table 8, are not statistically different from zero. This confirms that firms borrowing from banks with a high share of foreign funding as of December 2006 did not face any differential credit supply prior to the crisis. And, correspondingly, their exports' performance was not different from that of firms linked to banks with a low share of foreign funding.

Overall, the results in in this section suggest that our empirical approach obtains unbiased estimates of the elasticity of exports to credit. In other words, after conditioning on product-destination shocks to exports, a firm's affiliation to a bank with a high share of foreign funding is orthogonal to other non-credit determinants of exports.

\subsection{Discussion of the Results}

Our results are consistent with models of heterogeneous firms — as in Melitz (2003) expanded to allow for multi-product output and exports, as in Bernard et al. (2011) and Nocke and Yeaple (2014). A firm decides to export a product to a destination if the corresponding flow of profits covers an initial entry cost. In this class of models, a shock that affects the variable cost of production can generate a drop in the intensive margin of exports in all those firm-product-destination flows that remain active. In other words, our results are consistent with credit shocks affecting the variable cost of production, as modeled in Feenstra et al. (2014) and Manova (2013). This is the case, for example, if the credit shock implies an increase in the cost of external finance needed to pay inputs in advance of receiving the revenues from production. Then, a deterioration in credit conditions lowers the equilibrium size and profitability of each export flow, which, in turn, may reduce the probability of entering new markets - as we find when the period of analysis is extended to two years (Table 8, Panel 5). Similar results can also arise if the credit shock affects the variable cost of exporting beyond that of production; however, we show in Subsection 5.2 that we do not find evidence supporting this interpretation.

Our results are not consistent with models in which credit is used to pay only the entry or fixed cost of exporting, as in Chaney (2005) and Caggese and Cuñat (2012), or the fixed capital investment, as in Brooks and Dovis (2012) and Leibovici (2013). In those models, credit shocks affect the entry decision but not the intensive margin of exports. Needless to say, our results do not imply that those credit motives are not present. They point to two different usages of credit, the finance of working capital of production and the funding of physical investment.

The fact that credit conditions affect the variable cost of production, rather than only the fixed investment or entry cost, implies that short-lived credit shocks can have large real economic consequences. First, if credit conditions affected only fixed investment or entry cost, the real consequences would be small because capital is a stock variable and it does not substantially vary with short-lived shocks. Second, shocks to entry costs can hardly affect aggregate exports, which are accounted for mainly by existing large exporters (marginal export flows due to the exit or entry of firms into export markets are typically small). In contrast, shocks to the variable cost of production immediately 
affect the production and export decisions of both large and small firms. This is why macroeconomic models aimed at studying the dynamic consequences of financial shocks often include working capital in the production function (see, for example, Neumeyer and Perri (2005)).

\section{Assessment of Alternative Empirical Approaches}

Our empirical strategy requires detailed and disaggregated data typically not available in the literature that measures the effect of credit shocks on real economic activity. In the absence of such data, researchers have relied on theory-motivated identification assumptions that have not been tested empirically. The data and empirical strategy in this paper allow us to test several of the key assumptions in existing empirical work. First, we estimate the bias that would arise in our environment if we could not account for the selection of firms to banks in terms of their mix of products and destinations. Second, we analyze whether those variables typically used as proxy for export-specific funding needs are, indeed, predictors of the elasticity of exports to credit. And, finally, we explore the validity of the measure of external finance dependence - an industry-level indicator often used in this literature - as a proxy for sensitivity of output to credit.

\subsection{Firm-Bank Selection}

Most of the work studying real effects of the bank transmission channel is constrained to the analysis of firm-level outcomes, such as total sales, total exports, employment or investment 20 The typical empirical strategy compares outcomes of firms related to banks that are differentially affected by the crisis, and it implicitly assumes that banks and firms are randomly matched. If, however, firms related to exposed banks specialize in certain products or markets that are particularly affected by the crisis, then estimates based on comparing the outcomes of firms related to exposed and non-exposed banks confound the effect of the lending channel with the heterogeneous impact of the crisis across markets.

We compute the bias that arises in our setting when we do not account for shocks at the product-destination level. Column 1 of Table 9, presents the naive estimation of the elasticity of exports (intensive margin) to credit, without including the product-destination dummies. The naive estimator is off by a factor of two relative to the benchmark regression (our baseline estimate is shown in column 2 for comparison). This implies that firms and banks are not randomly matched. In particular, in this case, firms borrowing from exposed banks specialize in products and destinations less affected by the international crisis ${ }^{21}$ Thus, when non-finance shocks at the product-destination level are unaccounted for, the overall importance of credit shocks in explaining output fluctuations can be severely

\footnotetext{
${ }^{20}$ See, for example, Amiti and Weinstein (2011), Chodorow-Reich (2014), Carvalho et al. (2014), Iyer et al. (2014), Jimenez et al. (2011), Kalemli-Ozcan et al. (2010), and Muûls (2012).

${ }^{21}$ The bias is largest when there are no controls for changes in export demand across destination markets (not shown).
} 
misevaluated. In the present case, the bias would lead to the erroneous conclusion that the negative credit shocks did not contribute to the Peruvian exports decline.

\subsection{Export-Specific Funding Needs}

Substantial fixed exporting costs can make exports more sensitive to credit than domestic sales are, as changes in the exporter's availability of credit may trigger discontinuous changes in exports. Furthermore, international trade is characterized by longer freight times and, thus, longer cash cycles than domestic sales. Based on this intuition, the empirical literature uses distance to destination and freight speed (ground and sea versus air) as indicators of export-specific working capital ${ }^{22}$ In order to estimate export-specific credit sensitivity, this approach compares the impact of credit on exports across destinations of heterogeneous distance or across products typically shipped by different modes of transportation.

The results in the previous subsection already call for caution when deriving conclusions regarding the importance of credit in explaining output fluctuations based on comparisons across sectors or destinations. This is so because products and countries are subject to different non-credit disturbances. This empirical strategy confounds exportspecific sensitivity to credit with non-credit shocks disproportionately affecting certain products or destinations. To further characterize the potential biases in such comparisons, we present in Table 9, columns 3 through 8, cross-sectional differences in the estimated elasticities by distance to the export destination market $\left(D i s t_{d}\right)$; the share of the export flow shipped by air, as opposed to ground and sea $\left(A i r_{i p d}\right)$; and the share of the export flow paid in advance by the importer $\left(C_{a s h} h_{i p d}\right)$, with and without accounting for productdestination shocks. The variables $D i s t_{d}, A i r_{i p d}$, and $C a s h_{i p d}$ are standardized Pre period values such that the interaction coefficients can be interpreted as changes in the elasticity for a one-standard-deviation change in distance to destination, fraction of air freight and fraction of cash in advance, respectively.

Two main observations can be drawn from this exercise. First, the elasticity estimates accounting for product-destination shocks do not vary in the cross-section by distance, freight method, or method of payment (columns 4, 6, and 8). This indicates that the difference in working-capital requirements induced by heterogeneity along these export dimensions does not have a first-order effect on the export elasticity to credit. Since we do not have data on domestic sales, we cannot conclusively compare the credit elasticity of exports and local sales. Still, we can confirm that the sensitivity of exports to credit shocks does not vary significantly with variables that typically proxy for export-specific financial needs in our setting.

The second observation is that when product-destination shocks are not accounted for, the interaction terms for method of payment and freight method become statistically significant (the interaction with distance remains insignificant). Hence, the estimates would erroneously suggest that the sensitivity of exports to credit shocks increases if

\footnotetext{
${ }^{22}$ See, for example, Amiti and Weinstein (2011), Leibovici and Waugh (2013), and Berman et al. $(2012)$ ).
} 
the export flow is shipped primarily by air (column 5), and decreases if the importer pays for the export flow in advance (column 7). This analysis confirms that empirical approaches based on cross-destination and cross-sector comparisons may lead to incorrect inferences about the real effects of credit shocks when demand factors are unaccounted for. Moreover, the bias of the naive cross-sectional comparisons highlights that the modes of payment and transportation are intimately linked with the nature of the exported good. For example, products typically shipped by Air are presumably more expensive, and their demand may have suffered disproportionately more during the crisis.

\subsection{Sectoral Heterogeneity in Credit Intensity}

Since the seminal work by Rajan and Zingales (1998), heterogeneity in the degree of external finance dependence across sectors has been widely used to identify the effect of credit constraints on long-term growth and the cross-country pattern of international trade. ${ }^{23}$ It remains to be shown whether the same factors that affect the sensitivity of exports to long-term finance can also predict the effect of short-term credit shocks. This subsection explores that question.

We analyze how our estimates of the export elasticities to credit shocks vary across sectors with different external finance dependence. Our measure of external finance dependence follows Chor and Manova (2012); it corresponds to the fraction of total capital expenditures not financed by internal cash flows, according to cross-sectoral data on U.S. firms. This measure is considered to represent technological characteristics of the sector that the firm belongs to. For example, according to this measure, textile mills that transform basic fibers into fabric, intensively require external finance, while apparel manufacturing firms that process that fabric into the final piece of clothing are considered less dependent.

We report in Table 10 the results of estimating the elasticity of exports to credit on the intensive and extensive margins in equations (11) and (4), augmented with an interaction with the (standardized) product's external financial dependence. The elasticities of the intensive and extensive margins do not vary with this measure.

Our results suggest that the elasticities to short-term and long-term changes in financial conditions capture different aspects of the firm's use of credit. The measure of external finance dependence may indicate the firm's sensitivity to long-term credit conditions, which is potentially related to the presence of important fixed investments or entry costs. The elasticity of the intensive margin of exports to credit shocks, on the other hand, appears to be related to the short-term needs of working capital.

\section{Conclusions}

This paper computes the elasticity of the intensive and extensive margins of export to credit supply shocks. We find that changes in credit conditions affect the intensive margin

${ }^{23}$ See, for example, Bricongne et al. (2012), Chor and Manova (2012), and Levchenko et al. (2010). 
of exports, but do not significantly affect the extensive margin. They do have an effect on the entry margin when the period is expanded to two years after the shock. These results imply that short-lived credit shocks can have large real economic consequences. This is because aggregate exports are hardly affected by the exit or entry of firms into export markets, as these marginal export flows are typically relatively small. However, variations in the intensive margin have first-order implications for aggregate figures.

We use the estimated elasticities to perform a back-of-the-envelope calculation of the contribution of finance to the overall export decline during the the 2008 crisis. Our estimates are obtained from changes in credit according to the level of foreign funding of commercial banks. Thus, to obtain a back-of-the-envelope calculation of the overall effect of the credit shock to firms on the decline in exports, we must make an assumption about the change in credit supply of non-exposed banks - i.e., banks with a share of foreign funding below 10\%. We make the simplifying assumption that the credit supply of nonexposed banks is constant throughout the analysis period. This assumption produces conservative estimates of the overall effect of credit if non-exposed banks also reduced credit supply during the crisis. The opposite occurs if non-exposed banks expanded credit supply to substitute for the unfulfilled demand by banks with higher share of foreign funding.

The estimates in Table 3 imply that banks with foreign funding above $10 \%$ reduced credit supply by $16.8 \%$ relative to not-affected banks. They account for $30 \%$ of the total credit to exporters during the 12 months before July 2008 (see Table 2). Given the above assumption, these estimates imply that the total credit supply dropped by $5.1 \%$. Using the estimated intensive margin elasticities of 0.195 (see column 2, Table 5), this drop in credit resulted in an average decrease in the volume of exports of $1 \%$. Compared to the total drop in the annual growth rate of the volume of exports between the Pre and Post periods, 12.8 percentage points, this estimate implies that the credit shock can account for approximately $8 \%$ of the missing volume of exports.

Overall, the results in this paper show that credit has a first-order effect on the volume of exports for firms that continued exporting to a given product and destination market. However, the largest determinant of the Peruvian exports collapse during the 2008 crisis is related to non-credit factors (e.g., international demand and prices). In our context, failure to control for determinants of exports other than bank credit at the productdestination level leads to severely biased estimates when studying the effect of a credit contraction on exports. Our results suggest that estimates that rely on more-aggregated data (e.g., outcomes at the firm or sector levels) should be interpreted with caution during crisis episodes, which have potentially large and heterogeneous real effects across sectors and countries.

\section{References}

Alessandria, G., Kaboski, J. and Midrigan, V. (2010), 'The Great Trade Collapse of 2008-09: an Inventory Adjustment?', IMF Economic Review 58(2), 254-294. 
Amiti, M. and Weinstein, D. (2011), 'Exports and Financial Shocks', The Quartely Journal of Economics 126(4), 1841-1877.

Antras, P. and Foley, F. (2014), 'Poultry in Motion: A Study of International Trade Finance Practices', Journal of Political Economy forthcoming.

Arellano, M. (2003), Panel Data Econometrics, Advanced Texts in Econometrics, Oxford University Press.

Baldwin, R. and Krugman, P. (1989), 'Persistent Trade Effects of Large Exchange Rate Shocks', The Quarterly Journal of Economics 104(4), 635-654.

Banco Central de Reserva del Peru (2009), 'Reporte de estabilidad financiera'. May.

Beck, T. (2002), 'Financial Development and International Trade. Is there a Link?', Journal of International Economics 57(1), 107-131.

Belloni, A., Chen, D., Chernozhukov, V. and Hansen, C. (2012), 'Sparse Models and Methods for Optimal Instruments With an Application to Eminent Domain', Econometrica 80(6), 2369-2429.

Bems, R., Johnson, R. and Yi, K.-M. (2010), 'Demand Spillovers and the Collapse of Trade in the Global Recession', IMF Economic Review 58, 295-326.

Berman, N., De Sousa, J., Martin, P. and Mayer, T. (2012), 'Time to Ship during Financial Crises', NBER Working Paper 18274.

Berman, N. and Hericourt, J. (2010), 'Financial Factors and the Margins of Trade: Evidence from Cross-Country Firm-Level Data', Journal of Development Economics 93(2), 206-217.

Bernanke, B. (1983), 'Non Monetary Effects of the Financial Crisis in the Propagation of the Great Depression', The American Economic Review 73(3), 257-276.

Bernanke, B. and Blinder, A. (1992), 'The Federal Funds Rate and the Channels of Monetary Transmission', The American Economic Review 82(4), 901-921.

Bernard, A., Redding, S. and Schott, P. (2011), 'Multi-Product Firms and Trade Liberalization', Quarterly Journal of Economics 126(3), 1271-1318.

Bolton, P., Chen, H. and Wang, N. (2011), 'A Unified Theory of Tobin's q, Corporate Investment, Financing, and Risk Management', The Journal of Finance 66(5), 15451578.

Bricongne, C., Fontagne, L., Gaulier, G., Taglioni, D. and Vicard, V. (2012), 'Firms and the global crisis: French exports in the turmoil', Journal of International Economics 87(1), 134-146. 
Brooks, W. and Dovis, A. (2012), 'Credit Market Frictions and Trade Liberalization'. Available at http://www3.nd.edu/ wbrooks/Research.html.

Caggese, A. and Cuñat, V. (2012), 'Financing Constraints, Firm Dynamics, Export Decisions, and Aggregate Productivity', Review of Economic Dynamics 16(1), 177-193.

Carvalho, D., Ferreira, M. and Matos, P. (2014), 'Lending Relationship and the Effect of Bank Distress: Evidence from the 2007-2008 Financial Crisis', Journal of Financial and Quantitative Analysis forthcoming.

Cetorelli, N. and Goldberg, L. (2011), 'Global Banks and International Shock Transmission: Evidence from the Crisis', IMF 59(1), 41-76.

Chaney, T. (2005), 'Liquidity Constrained Exporters'. Available at https://sites.google.com/site/thomaschaney/research.

Chodorow-Reich, G. (2014), 'The Employment Effects of Credit Market Disruptions: Firm-Level Evidence from the 2008-09 Financial Crisis', Quarterly Journal of Economics 129(1), 1-59.

Chor, D. and Manova, K. (2012), 'Off the Cliff and Back? Credit Conditions and International Trade during the Global Financial Crisis', Journal of International Economics 87, 117-133.

Eaton, J., Kortum, S., Neiman, B. and Romalis, J. (2010), 'Trade and the Global Recession', Available at http://home.uchicago.edu/kortum/skresearch.html .

Feenstra, R., Li, Z. and Yu, M. (2014), 'Exports and Credit Constraint under Incomplete Information: Theory and Evidence from China', The Review of Economics and Statistics forthcoming.

Friedman, M. and Schwarz, A. (1963), Monetary History of the United States, 1867-1960, Princeton University Press.

Gan, J. (2007), 'The Real Effects of Asset Market Bubbles: Loan- and Firm-Level Evidence of a Lending Channel', Review of Financial Studies 20(5), 1941-1973.

IMF (2009), 'World economic outlook'. April.

Iyer, R., Lopes, S., Peydro, J.-L. and Schoar, A. (2014), 'Interbank Liquidity Crunch and the Firm Credit Crunch: Evidence from the 2007-2009 Crisis', Review of Financial Studies forthcoming.

Iyer, R. and Peydro, J.-L. (2011), 'Interbank Contagion at Work: Evidence from a Natural Experiment', Review of Fi 24(4), 1337-1377.

Jimenez, G., Mian, A., Peydro, J.-L. and Saurina, J. (2011), Local versus Aggregate Lending Channels: The Effects of Securitization on Corporate Credit Supply in Spain. Available at http://ssrn.com/abstract $=1674828$. 
Jimenez, G., Ongena, S., Peydro, J.-L. and Saurina, J. (2012), 'Credit Supply and Monetary Policy: Identifying the Bank Balance-Sheet Channel with Loan Applications', The American Economic Review 102(5), 2301-2326.

Kalemli-Ozcan, S., Kamil, H. and Villegas-Sanchez, C. (2010), 'What Hinders Investment in the Aftermath of Financial Crises? Insolvent Firms or Illiquid Banks', NBER Working Paper. 16528.

Kashyap, A., Lamont, O. and Stein, J. (1994), 'Credit Conditions and the Cyclical Behavior of Inventories', Quarterly Journal of Economics 109(3), 565-592.

Kashyap, A. and Stein, J. (2000), 'What do One Million Observations on Banks Have to Say About the Transmission of Monetary Policy', The American Economic Review $\mathbf{9 0}(3), 407-428$.

Khwaja, A. and Mian, A. (2008), 'Tracing the Impact of Bank Liquidity Shocks: Evidence from an Emerging Market', The American Economic Review 98(4), 1413-1442.

Leibovici, F. (2013), Financial Development and International Trade. Available at http://dept.econ.yorku.ca/ flei/.

Leibovici, F. and Waugh, M. (2013), International Trade and Intertemporal Substitution. Available at http://dept.econ.yorku.ca/ flei/.

Levchenko, A., Lewis, L. and Tesar, L. (2010), 'The Collapse of International Trade during the 2009-2009 Crisis: In Search of the Smoking Gun', IMF Economic Review 58(2), 214-253.

Manova, K. (2013), 'Credit Constraints, Heterogeneous Fimrs, and International Trade', Review of Economic Studies 80, 711-744.

Manova, K., Wei, S.-J. and Zhang, Z. (2014), 'Firm Exports and Multinational Activity under Credit Constraints', Review of Economics and Statistics forthcoming.

Melitz, M. J. (2003), 'The Impact of Trade on Intra-Industry Reallocations and Aggregate Industry Productivity', Econometrica 71(6), 1695-1725.

Minetti, R. and Zhu, S. C. (2011), 'Credit Constraints and Firm Export: Microeconomic Evidence from Italy', Journal of International Economics 83(2), 109-125.

Mulligan, C. B. and Rubinstein, Y. (2008), 'Selection, Investment, and Women's Relative Wages Over Time', The Quarterly Journal of Economics 123(3), 1061-1110.

Muûls, M. (2012), 'Exporters, importers, and credit constraints', CEP Discussion Paper 1169.

Neumeyer, P. A. and Perri, F. (2005), 'Business Cycles in Emerging Economies: the Role of Interest Rates', Journal of Monetary Economics 52(2), 345-380. 
Nocke, V. and Yeaple, S. (2014), 'Globalization and Multiproduct Firms', International Economic Review forthcoming.

Paravisini, D. (2008), 'Local Bank Financial Constraints and Firm Access to External Finance', The Journal of Finance 63(5), 2160-2193.

Peek, J. and Rosengren, E. (2000), 'Collateral Damage: Effects of the Japanese Bank Crisis on Real Activity in the United States', The American Economic Review 90(1), 30-45.

Puri, M., Rocholl, J. and Steffen, S. (2011), 'Global retail lending in the aftermath of the US financial crisis: Distinguishing between supply and demand effects', Journal of Financial Economics 100(3), 556-578.

Rajan, R. and Zingales, L. (1998), 'Financial Dependence and Growth', The American Economic Review 88(3), 559-586.

Rauch, J. (1999), 'Networks Versus Markets in International Trade', Journal of International Economics 48(1), 7-35.

Roberts, M. and Tybout, J. (1999), 'An Empirical Model of Sunk Costs and the Decision of Exports', World Bank Working Paper 1436 .

Schnabl, P. (2012), 'Financial Globalization and the Transmission of Bank Liquidity Shocks: Evidence from an Emerging Market', The Journal of Finance 67(3), 897-932. 
Figure 1: Peruvian International Flows During 2008 Financial Crisis

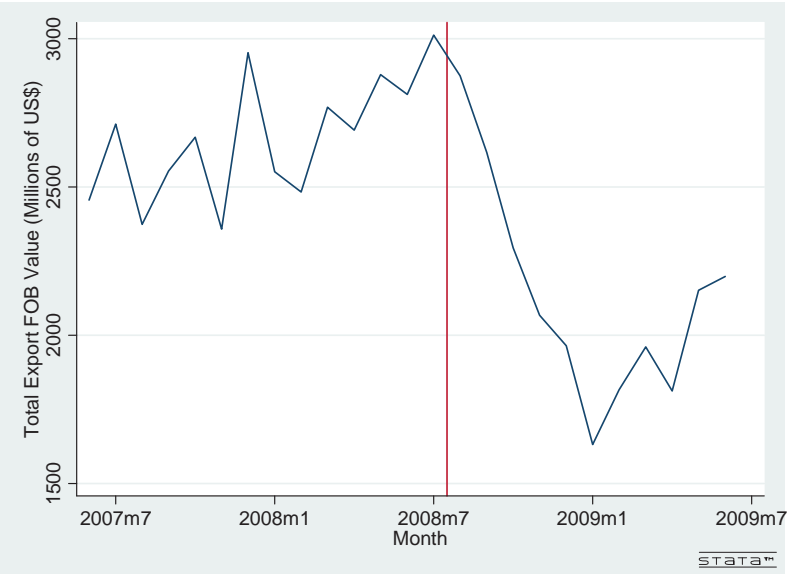

(a) Total Peruvian Exports

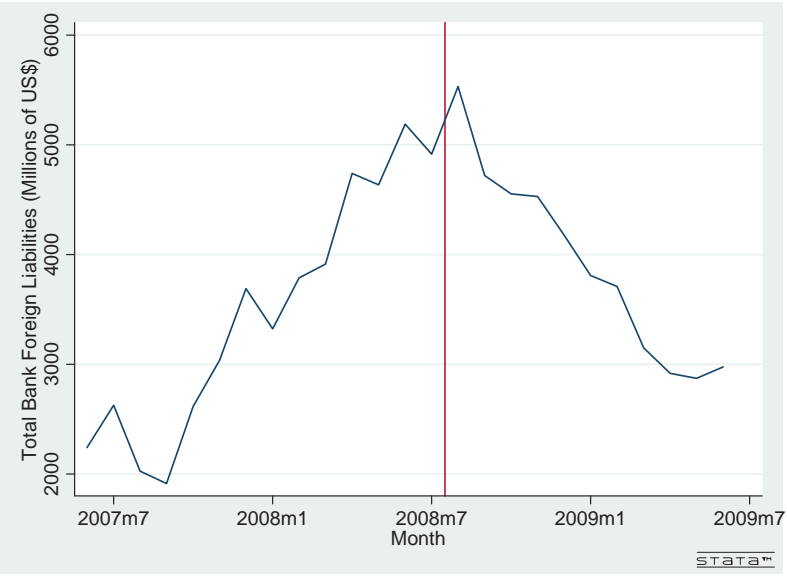

(b) Total Banking Sector Foreign Financing

Source: Export data are collected from the Peruvian tax agency. Data on foreign liabilities of the banking sector are derived from bank balance sheets, which were collected from the Peruvian bank regulator. Total bank foreign liabilities are defined as bank liabilities with institutions outside Peru. The vertical line signals the Pre and Post periods, which correspond to the 12 months before and after July 2008.

Figure 2: Bank Credit and Foreign Funding

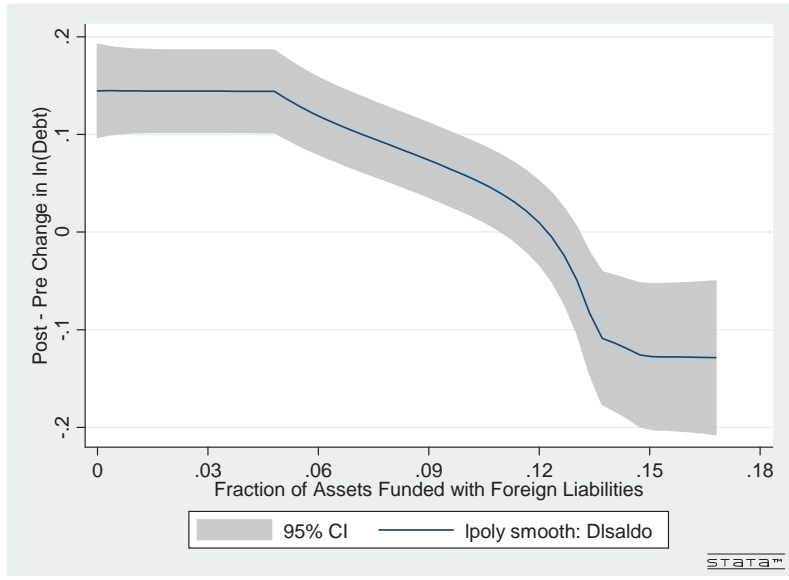

(a) Change in Total Credit

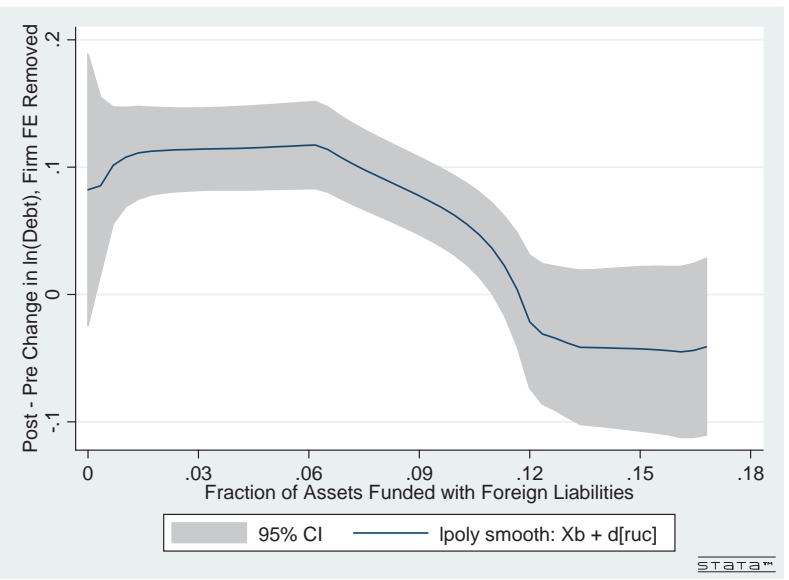

(b) Change in Credit Supply

Note: Y-axis in panel (a) is change in (log) credit between the Post and Pre periods, $\ln C_{i b P o s t}-\ln C_{i b P r e}$. In panel (b) is the residual of a regression of change in (log) credit on a full set of firm fixed-effects: $\ln C_{i b P o s t}-\ln C_{i b P r e}=\theta_{i}+\epsilon_{i b}$. In both cases, the graph is a weighted local second-degree polynomial smoothing of the share of banks' foreign funding as of December 2006. The observations are weighted using an Epanechnikov kernel with a bandwidth of 0.03 . 
Figure 3: Heterogeneity of the Export Elasticity to Credit

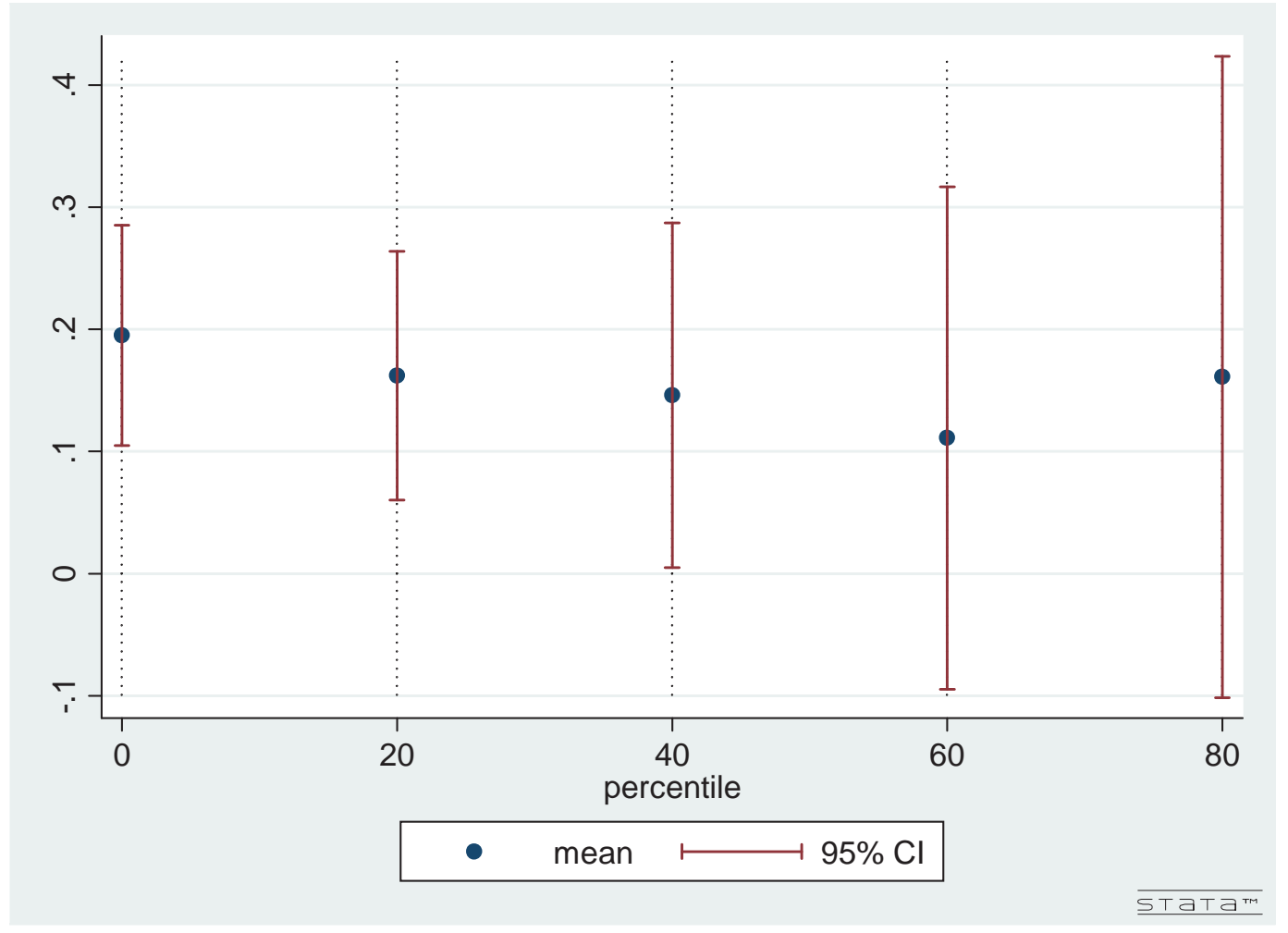

Note: Elasticity of the intensive margin of export to credit (and 95\% confidence interval) when restricting the sample to those active export flows with probability of continuation in the percentile indicated in the horizontal axes. 


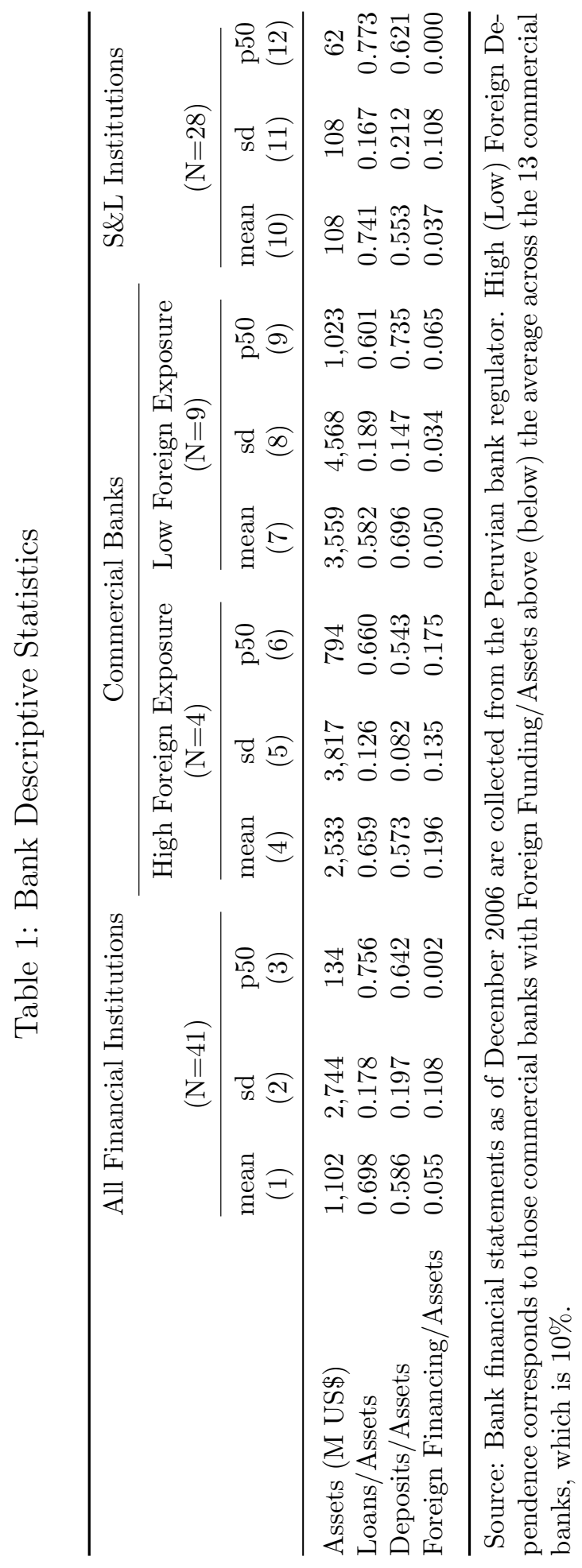




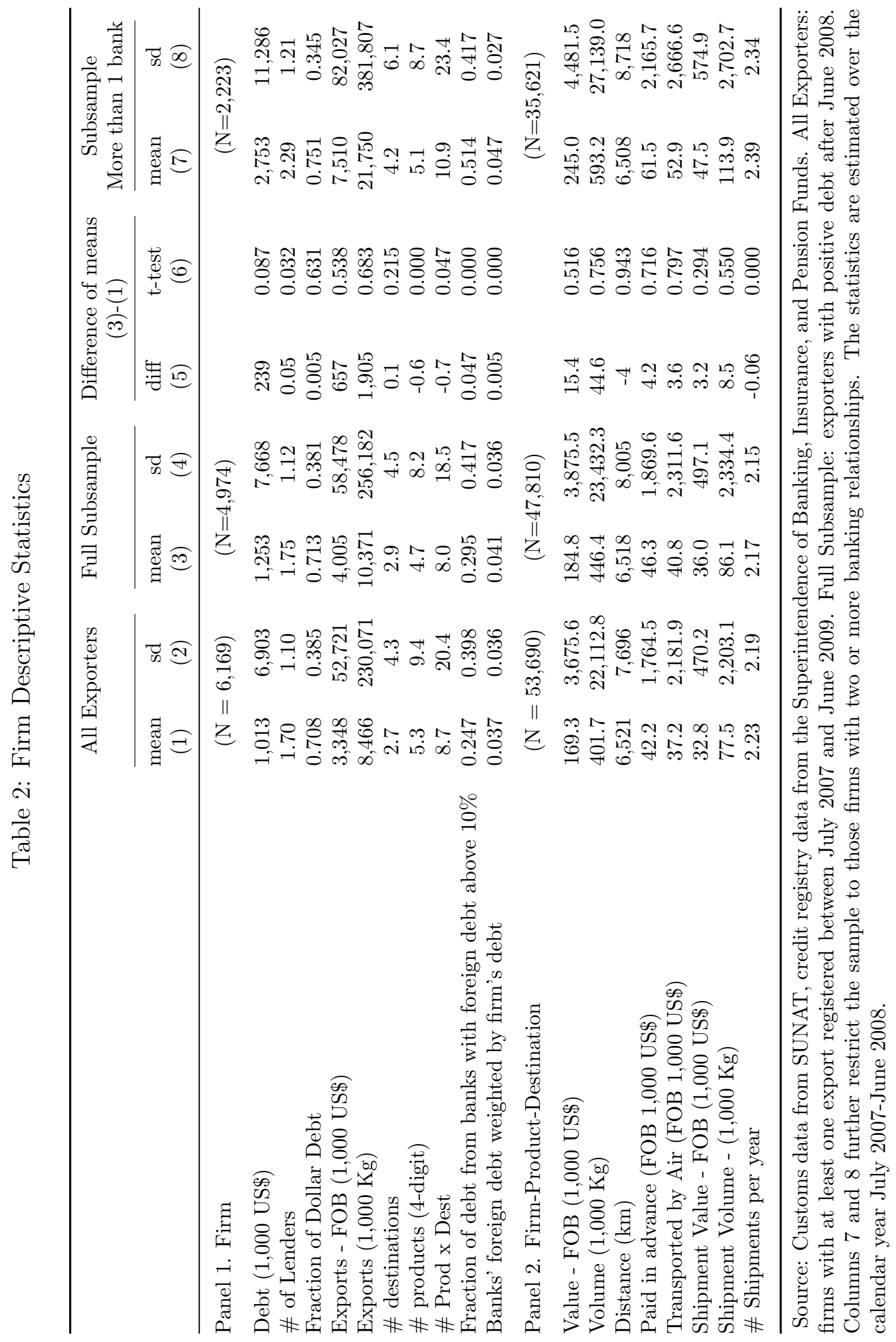


Table 3: Transmission of Credit Shocks by Banks

\begin{tabular}{lcc}
\hline Dependent Variable & \multicolumn{2}{c}{$\Delta \ln C_{i b}$} \\
\cline { 2 - 3 } & $(1)$ & $(2)$ \\
\hline$F D_{b}$ & $-1.881^{*}$ & \\
& $(1.008)$ & \\
$D\left(F D_{b}>10 \%\right)$ & & $-0.168^{* * *}$ \\
& & $(0.046)$ \\
Firm FE & Yes & Yes \\
Observations & 10,334 & 10,334 \\
$R^{2}$ & 0.630 & 0.630 \\
$R^{2}$ adj & 0.261 & 0.261 \\
$\#$ banks & 41 & 41 \\
$\#$ firms & 4,974 & 4,974 \\
\hline
\end{tabular}

Estimation of equation (8). $F D_{b}$ is the share of foreign funding of bank $b$. $D\left(F D_{b}>\overline{F D}\right)$ is a dummy that signals whether foreign funding of bank $b$ is above the mean among commercial banks, $10 \%$. Of the 4,974 firms in the regression, 2,223 have outstanding debt with two or more banks in the Pre period. Robust standard in parentheses, allowing for correlation at the product-destination level. ${ }^{* * *} p<0.01$, ${ }^{* *} p<0.05$, and ${ }^{*} p<0.1$ 
Table 4: First Stage with Different Instrumental Variable Functional Forms

\begin{tabular}{lccc}
\hline Dependent Variable & \multicolumn{3}{c}{$\Delta \ln C_{i}$} \\
\cline { 2 - 4 } & $(1)$ & $(2)$ & $(3)$ \\
\hline$\sum_{b} \omega_{i b} \times D\left(F D_{b}>\overline{F D}\right)$ & $-0.991^{* * *}$ & & \\
$\sum_{b} \omega_{i b} \times F D_{b}$ & $(0.092)$ & & \\
$\sum_{b} \omega_{i b} \times F D_{b}^{2}$ & & $-6.001^{* * *}$ & $33.9^{* * *}$ \\
$\sum_{b} \omega_{i b} \times F D_{b}^{3}$ & & $(1.324)$ & $(6.6)$ \\
& & & $-689.3^{* * *}$ \\
& & & $(120.3)$ \\
Product-Destination FE & & & $2,863.7^{* * *}$ \\
Observations & Yes & Yes & \\
$R^{2}$ & 14,208 & 14,210 & Yes \\
F-Statistic $(1,5995)$ & 0.371 & 0.353 & 0.394 \\
F-Statistic $(3,5995)$ & 115.52 & 20.53 & \\
& & & 13.78
\end{tabular}

Estimation of first-stage (9) with instrument $F_{i}=$ $\sum_{b} \omega_{i b} f\left(F D_{b}\right)$, where $\omega_{i b}$ is the share of firm- $i$ 's outstanding credit with bank $b$. In column $1, f\left(F D_{b}\right)=D\left(F D_{b}>10 \%\right)$ is a dummy equal to one if the bank's foreign funding is above the system's average, $10 \%$. In column $2, f\left(F D_{b}\right)=F D_{b}$ is the share of foreign debt of bank $b$. In column $3, f\left(F D_{b}\right)$ is a three-degree polynomial of $F D_{b}$. Robust standard errors in parentheses, allowing for correlation at the product-destination level. ${ }^{* * *} p<0.01,{ }^{* *} p<0.05$, and ${ }^{*} p<0.1$ 


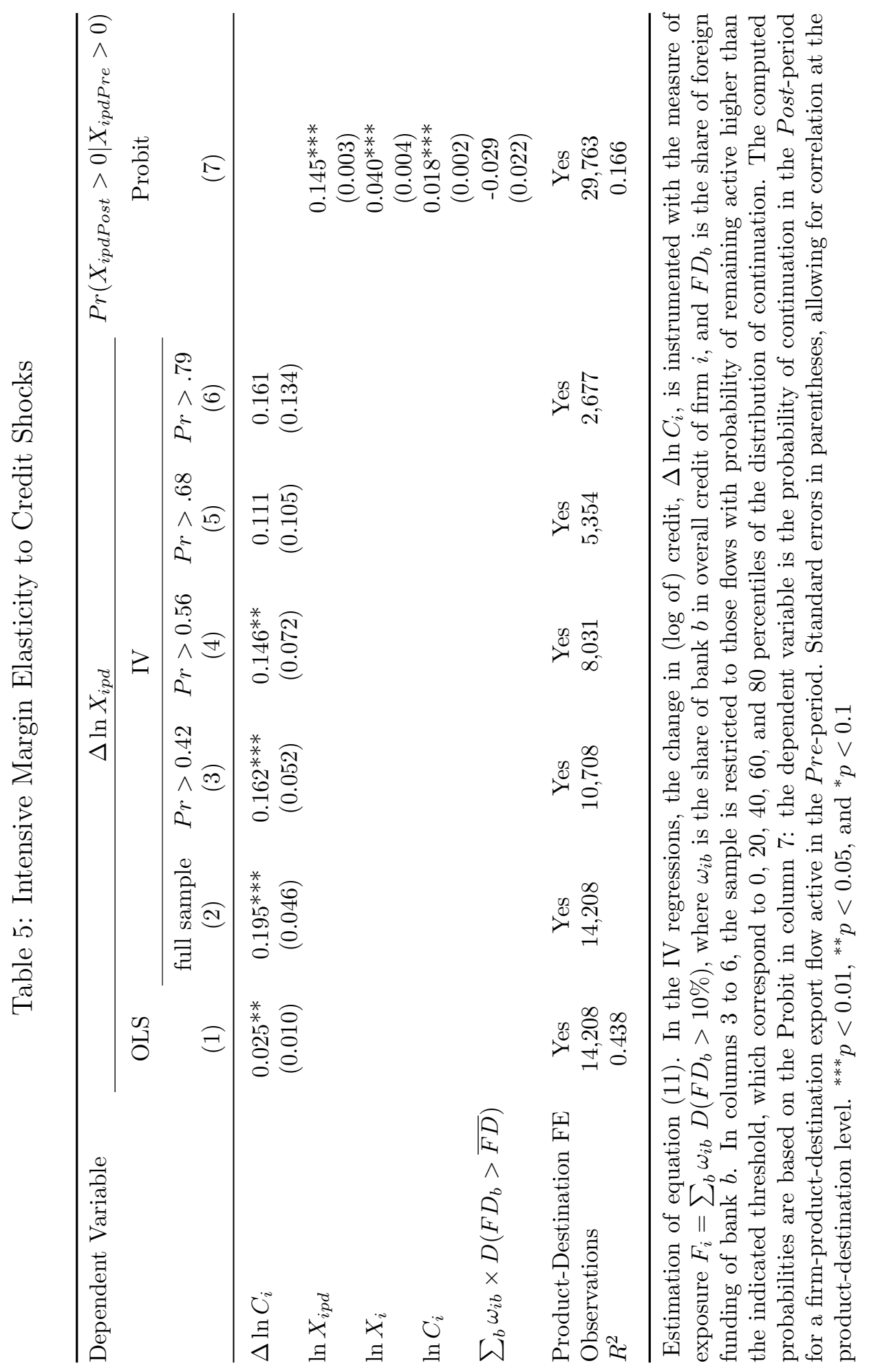


Table 6: Extensive Margin Elasticity to Credit Shocks

\begin{tabular}{|c|c|c|c|c|}
\hline \multirow[t]{2}{*}{ Dependent Variable } & \multicolumn{2}{|c|}{$\begin{array}{c}\operatorname{Pr}\left(X_{i p d t}=0 \mid X_{i p d t-1}>0\right) \\
\text { Exit }\end{array}$} & \multicolumn{2}{|c|}{$\begin{array}{c}\operatorname{Pr}\left(X_{i p d t}>0 \mid X_{i p d t-1}=0\right) \\
\text { Entry }\end{array}$} \\
\hline & $\begin{array}{l}\text { OLS } \\
(1)\end{array}$ & $\begin{array}{l}\text { IV } \\
(2)\end{array}$ & $\begin{array}{l}\text { OLS } \\
(3)\end{array}$ & $\begin{array}{l}\text { IV } \\
(4)\end{array}$ \\
\hline $\ln C_{i t}$ & $\begin{array}{l}-0.001 \\
(0.003)\end{array}$ & $\begin{array}{l}-0.04 \\
(0.011)\end{array}$ & $\begin{array}{c}0.015 \cdot 10^{-2} \\
\left(0.010 \cdot 10^{-2}\right)\end{array}$ & $\begin{array}{l}-0.001 \cdot 10^{-2} \\
\left(0.020 \cdot 10^{-2}\right)\end{array}$ \\
\hline Product-Destination-Time FE & Yes & Yes & Yes & Yes \\
\hline Firm FE & Yes & Yes & Yes & Yes \\
\hline Observations & 62,386 & 62,386 & $4,161,4651$ & $4,161,4651$ \\
\hline$R^{2}$ & 0.591 & & 0.520 & \\
\hline
\end{tabular}

Estimation of equation (4). In the IV regression, the (log of) credit, $\ln C_{i t}$, is instrumented with the measure of exposure $F_{i t}=\sum_{b} \omega_{i b} D\left(F D_{b}>10 \%\right)$ Post $_{t}$, where $\omega_{i b}$ is the share of bank $b$ in overall credit of firm $i$ and $F D_{b}$ is the share of foreign funding of bank $b$ and Post $_{t}$ is a dummy equal to one in the Post-period. Standard errors in parentheses, allowing for correlation at the product-destination level. ${ }^{* * *} p<0.01,{ }^{* *} p<0.05$, and ${ }^{*} p<0.1$ 


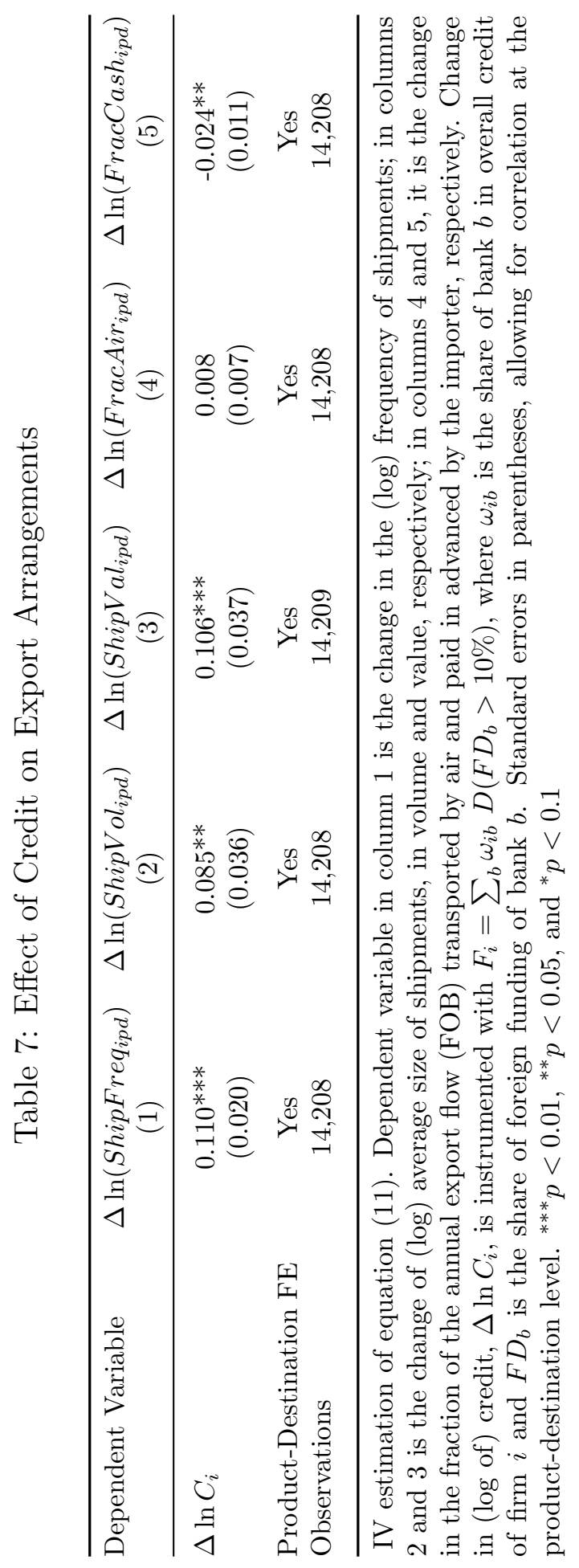


Table 8: Identification Tests

\begin{tabular}{ll}
\hline Dep. Variable & $\Delta \ln X_{i p d}$ \\
Intensive
\end{tabular}

(1)
$\begin{array}{cc}\operatorname{Pr}\left(X_{i p d t}=0 \mid X_{i p d t-1}>0\right) & \operatorname{Pr}\left(X_{\text {ipdt }}>0 \mid X_{i p d t-1}=0\right) \\ \text { Exit } & \text { Entry }\end{array}$

(2)

Panel 1: $X_{i p d}$ is Value (FOB) of Exports

$\Delta \ln C_{i}$ $0.217^{* * *} \quad \ln C_{i t}$ (0.046)

Panel 2: Product Classification at 6 HSdigits

$\Delta \ln C_{i} \quad 0.221^{* * *} \quad \ln C_{i t}$ $-0.046$

$-0.001$

$(0.009)$

Panel 3: Sample of Homogeneous Goods

$\Delta \ln C_{i}$ $0.183^{* * *} \quad \ln C_{i t}$ (0.048) $-0.011$ $(0.012)$

Panel 4: Controlling for Observable Firm Characteristics $\Delta \ln C_{i}$

$\ln X_{i}$

$\ln U S \$$ Debt $_{i} \quad 0.119^{*}$

UnitPrice $_{i p d} \quad 0.000$

$\ln \#_{\text {products }}$ pro $_{i} \quad 0.003$

$\ln \#_{\text {destination }}$ s $0.219^{* * *}$ (0.057) $-0.028^{* *}$

$(0.013)$ $(0.065)$

(0.000)

$(0.022)$

0.034

(0.029) $\ln C_{i t}$

$\ln X_{i} \times$ Post

$\ln U S \$$ Debt $_{i} \times$ Post

UPrice $_{i p d}$

UPrice $_{i p d} \times$ Post

$\ln$ prod $_{i} \times$ Post

$\ln$ \#dest $_{i} \times$ Post
$-0.016$

$(0.013)$

$-0.012^{* * *}$

$(0.004)$

$-0.030^{*}$

$(0.018)$

0.000

$(0.000)$

0.000

$(0.000)$

$-0.015^{* *}$

$(0.007)$

$-0.031^{* * *}$

(0.009)

$\ln C_{i t}$

$-0.014$

$(0.010)$

$0.189^{* * *}$
$(0.038)$

d of two years

$\Delta \ln C_{i}$

Panel 6: Measure of Exposure as of Dec 2007

$\Delta \ln C_{i}$

$$
\begin{array}{cc}
0.162^{* * *} & \ln C_{i t} \\
-0.054 &
\end{array}
$$$$
-0.015
$$$$
(0.013)
$$

Panel 7: Alternative IV functional form (Continuum 3rd-Degree Polynomial)

$\Delta \ln C$

$$
0.217^{* * *} \quad \ln C_{i t}
$$

$-0.028^{*}$

$0.000 \cdot 10^{-2}$

$\left(0.000 \cdot 10^{-2}\right)$

$-0.001 \cdot 10^{-2}$

$\left(0.021 \cdot 10^{-2}\right)$

$-0.006 \cdot 10^{-2}$

$\left(0.022 \cdot 10^{-2}\right)$

$-0.009^{*} \cdot 10^{-2}$

$\left(0.005 \cdot 10^{-2}\right)$

$0.024 \cdot 10^{-2}$

$\left(0.024 \cdot 10^{-2}\right)$

$$
\text { (0.064) }
$$

$\ln C_{i t}$

$-0.077$

$\Delta \ln C_{i}$

$-0.125$

(0.173)

$$
\begin{gathered}
-0.077^{* * *} \cdot 10^{-2} \\
\left(0.013 \cdot 10^{-2}\right) \\
-0.018 \cdot 10^{-2} \\
\left(0.022 \cdot 10^{-2}\right)
\end{gathered}
$$

Panel 8: Placebo Test

$0.001^{* * *} \cdot 10^{-2}$

$\left(0.000 \cdot 10^{-2}\right)$

$0.006 \cdot 10^{-2}$

$\left(0.022 \cdot 10^{-2}\right)$

$0.007 \cdot 10^{-2}$

$\left(0.027 \cdot 10^{-2}\right)$

$0.001 \cdot 10^{-2}$

$\left(0.001 \cdot 10^{-2}\right)$

IV estimations of (11) and (4). In Panel 7, $\Delta \ln C_{i}$ instrumented by a three-degree polynomial of $F_{i}=\sum_{b} \omega_{i b} F D_{b}$. In Panel 8, the placebo test assumes that the credit shock occurred a year earlier (June 2006). Standard errors in parentheses, allowing for correlation at the product-destination level. ${ }^{* * *} p<0.01,{ }^{* *} p<0.05$, and ${ }^{*} p<0.1$. 
Table 9: Estimation Bias

\begin{tabular}{|c|c|c|c|c|c|c|c|c|}
\hline \multirow[t]{2}{*}{ Dependent Variable } & \multicolumn{8}{|c|}{$\Delta \ln X_{i p d}$} \\
\hline & (1) & (2) & $(3)$ & (4) & (5) & (6) & (7) & (8) \\
\hline$\Delta \ln C_{i}$ & $\begin{array}{c}0.082 \\
(0.059)\end{array}$ & $\begin{array}{c}0.195^{* * *} \\
(0.046)\end{array}$ & $\begin{array}{c}0.098^{* *} \\
(0.041)\end{array}$ & $\begin{array}{c}0.177^{* * *} \\
(0.053)\end{array}$ & $\begin{array}{c}0.111^{* * *} \\
(0.037)\end{array}$ & $\begin{array}{c}0.195^{* * *} \\
(0.046)\end{array}$ & $\begin{array}{c}0.093^{* *} \\
(0.039)\end{array}$ & $\begin{array}{c}0.182^{* * * *} \\
(0.048)\end{array}$ \\
\hline$\Delta \ln C_{i} \times$ Dist $_{d}$ & & & $\begin{array}{l}-0.028 \\
(0.094)\end{array}$ & $\begin{array}{c}-0.062 \\
(0.055)\end{array}$ & & & & \\
\hline$\Delta \ln C_{i} \times A i r_{i p d}$ & & & & & $\begin{array}{l}0.065^{*} \\
(0.038)\end{array}$ & $\begin{array}{c}0.068 \\
(0.047)\end{array}$ & & \\
\hline $\operatorname{Air}_{i p d}$ & & & & & $\begin{array}{c}-0.084^{* * *} \\
(0.022)\end{array}$ & $\begin{array}{c}-0.132^{* * *} \\
(0.033)\end{array}$ & & \\
\hline$\Delta \ln C_{i} \times C_{a s h} i p d$ & & & & & & & $\begin{array}{l}-0.077^{*} \\
(0.039)\end{array}$ & $\begin{array}{l}-0.082 \\
(0.056)\end{array}$ \\
\hline Cash $_{i p d}$ & & & & & & & $\begin{array}{c}0.042 \\
(0.028)\end{array}$ & $\begin{array}{c}0.031 \\
(0.041)\end{array}$ \\
\hline Prod-Dest FE & No & Yes & No & Yes & No & Yes & No & Yes \\
\hline Observations & 14,208 & 14,208 & 14,146 & 14,146 & 14,208 & 14,208 & 14,208 & 14,208 \\
\hline
\end{tabular}

IV estimations of equation (11). The instrument $F_{i}$ is $\sum_{b} \omega_{i b} D\left(F D_{b}>10 \%\right)$, where $\omega_{i b}$ is the share of bank $b$ in overall credit of firm $i$ and $F D_{b}$ is the share of foreign funding of bank $b$. Credit is interacted with the following (standardized) variables: distance to market of destination $\left(\right.$ dist $\left._{d}\right)$, an indicator on whether the export flow was shipped by air $\left(A i r_{i p d}\right)$, and the fraction of the transaction paid in advance by the importer $\left(\mathrm{Cash}_{i p d}\right)$ in the Pre period. Standard errors in parentheses, allowing for correlation at the productdestination level. ${ }^{* * *} p<0.01,{ }^{* *} p<0.05$, and ${ }^{*} p<0.1$ 
Table 10: Elasticity by Product Characteristic

\begin{tabular}{|c|c|c|c|}
\hline Dependent Variable & $\begin{array}{c}\Delta \ln X_{i p d} \\
\text { Intensive Margin } \\
\text { (1) }\end{array}$ & $\begin{array}{c}\operatorname{Pr}\left(X_{i p d t}=0 \mid X_{i p d t-1}>0\right) \\
\text { Exit } \\
(2)\end{array}$ & $\begin{array}{c}\operatorname{Pr}\left(X_{i p d t}>0 \mid X_{i p d t-1}=0\right) \\
\text { Entry } \\
(3)\end{array}$ \\
\hline$\Delta \ln C_{i}$ & $\begin{array}{c}0.164^{* * *} \\
(0.049)\end{array}$ & & \\
\hline$\Delta \ln C_{i} \times$ HighFinDep & $\begin{array}{l}-0.132 \\
(0.084)\end{array}$ & & \\
\hline $\ln C_{i t}$ & & $\begin{array}{c}0.008 \\
(0.014)\end{array}$ & $\begin{array}{c}0.006 \cdot 10^{-2} \\
\left(0.021 \cdot 10^{-2}\right)\end{array}$ \\
\hline $\ln C_{i t} \times$ HighFinDep & & $\begin{array}{c}0.065 \\
(0.055)\end{array}$ & $\begin{array}{c}0.001 \cdot 10^{-2} \\
\left(0.004 \cdot 10^{-2}\right)\end{array}$ \\
\hline Product-Destination FE & Yes & No & No \\
\hline Product-Destination-Time FE & No & Yes & Yes \\
\hline Firm FE & No & Yes & Yes \\
\hline Observations & 14,208 & 56,215 & $4,119,771$ \\
\hline
\end{tabular}

IV estimation of equations (11) and (4). The $\left(\log\right.$ of) credit, $\ln C_{i}$, is instrumented with $F_{i}=$ $\sum_{b} \omega_{i b} D\left(F D_{b}>10 \%\right)$, where $\omega_{i b}$ is the share of bank $b$ in overall credit of firm $i$ and $F D_{b}$ is the share of foreign funding of bank $b$. The classification of sectors according to their dependence of external finance follows Chor and Manova (2012). Standard errors in parentheses, allowing for correlation at the product-destination level. ${ }^{* * *} p<0.01,{ }^{* *} p<0.05$, and ${ }^{*} p<0.1$ 